\title{
Potenciál využití soukromých vojenských a bezpečnostních společností nevládními organizacemi
}

\author{
Vendula Nedvědická ${ }^{1}$ \\ Článek je výstupem z grantu P408/11/0395 Privatizace bezpečnosti: Role aktéri privátního seletoru v reakcích na

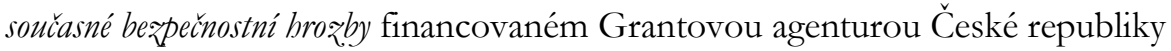

Abstract: Private Military and Security Companies and the Potential for their Use by Non-Governmental Organisations.

The paper deals with private military and security companies (PMSCs) providing their services for nongovernmental organisations (NGOs). It includes a brief overview of the security environment from 1990 and how PMSCs have developed since then. There is also an analysis of the motivations behind the NGOs' decisions to use the services of PMSCs and of cases when their services were used in practise. The paper attempts to explain the basis of the co-operation between these two parties during bumanitarian operations and explores services provided by the PMSCs to NGOs. The author also considers the key prerequisites for successful co-operation between these two parties, as well as the other options, if any, which are available to NGOs in the area of security..

Keywords: Private military and security companies, Non-governmental organisations

\section{1. Úvod}

NGOs by mèly zuážit privatizaci beapečnosti pro humanitárni úcely (...) Hlavni dilema spočivá v tom, že bumanitárni pracovnici se potýkaji s útočniky, kterí maji za obèt' civilni obyvatelstvo a pracovníky nevládních

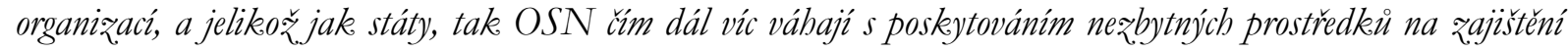
beapečnosti, stoji za to zváăit, zda v rámci privatizace pomoci by bylo vhodné privatizovat i beapečnost (Bryans, Jones a Stein, 1999: 2).

V 90. letech 20. století začínají odborníci z oblasti mezinárodních vztahů popisovat zajímavý jev. Tím je posun moci od státních aktérů směrem k nestátním aktérům. V časopise Foreign Affairs vychází článek Jessici Tuchman „Power Shift“, který tento jev popisuje: Národní vlády jednoduše nežtrácí autonomii v globalizujici ekonomice. Sdílejí moc - věetně politických, sociálních a beäpečnostních rolí v jádru suverenity - spodniky, mezinárodnimi organizacemi a rüznými skupinami obyvatel známými jako nevládni organizace (NGOs). Stabilni koncentrace moci v rukou státu, která začala v roce 1648 Vestfálským mirem, je u konce, alespoň na nèjakou chvíli (Mathews 1997: 50). Jako vysvětlení tohoto jevu se uvádí zejména neschopnost státu a mezinárodních institucí dostatečně reagovat na sociální, ekonomické a politické změny $\mathrm{v}$ důsledku pokroku technologií, globalizace a politické fragmentace (McGrann a Johnstone, 2006). Výše uvedená hypotéza se přinejmenším potvrzuje u současného působení soukromých vojenských a bezpečnostních společností (SVBS, private military and security companies) a nevládních organizací (NGOs, non-governmental organisations) v mezinárodním prostředí. Nicméně vstup těchto aktérů do mezinárodních vztahů je také spojen $\mathrm{s}$ řadou nových témat, která je potřeba řešit.

\footnotetext{
${ }^{1}$ Studentka doktorského program na Metropolitní univerzitě Praha, Dubečská 900/10, 10000 Praha 10 - Strašnice, vendula.nedvedicka@seznam.cz.
} 
$\mathrm{Na}$ jedné straně jsou soukromé firmy, které poskytují služby bezpečnostně-vojenského charakteru v rozličných situacích, a na straně druhé etablované organizace, které cílí především do sociální oblasti - oba aktéři jsou uznávanými a mezinárodním společenstvím prúijímanými členy. Oba aktéry kromě „nestátního“ charakteru spojuje i společný problém s jejich přesným definováním a vymezením, a to zejména z toho důvodu, že jejich působnost je velmi široká.

SVBS lze zjednodušeně definovat (s využitím poměrně zdařilé definice Sebastiana Deschampse vytvořené na základě využití SVBS Organizací spojených národů pro její operace) jako aktéry, kteři splňují tyto principy: a) Poskytuji vojenské rěseneni svým klientưm, logistiku, zbrané, výcvike, informace, pracovni silu atd.; b) [SVBS] jsou soukromé společnosti bez jakéhokoliv formálni vazby na

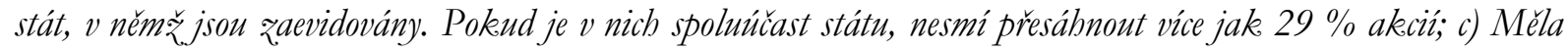
by to být instituce vytvorená pro podnikáni jako firma, která je komerčnè zaregistrována podle práva zemè, kde je jeji sídlo; d) Mèla by mit prèdstavenstvo ${ }^{3}$ s čelnimi predstaviteli, keteř̀ museji být právnè identifikovaní, a mùrèe mít akcionáre; e) MUSÍ dodržovat Ženevské úmluvy a Mezinárodni humanitárni právo; f) NESMÍ raměstnávat, platit, školit nebo usnadnit nábor žoldnério (Deschamps 2005: 16-17).

Za zmínku určitě stojí první mezinárodně právní dokument navržený Organizací spojených národů (OSN), který se zabývá SVBS (nikoliv žoldnéŕi, jak tomu bylo doposud), pojmenovaný Mezinárodni úmluva o regulaci, kontrole a monitoringu soukromých vojenských a beąpečnostnich společností zatím se jedná pouze o pracovní verzi, nikoliv o závazný dokument. Zde je uvedeno, že „Soukromá vojenská a/nebo bezpečnostní společnost (SVBS) je právnická osoba, která poskytuje za úplatu vojenské a/nebo bezpečnostní služby, včetně vyšetřovacích služeb, fyzickými a/nebo právnickými osobami“" (International Convention on the Regulation, Oversight and Monitoring of Private Military and Security Companies, 2009). Toto je velmi obecná definice SVBS - úmluva si nedává za cíl nalézt správnou definici SVBS, ale spíše zachytit užití těchto společností. Je také potřeba SVBS odlišovat od již zmiňovaných žoldnéřu: žoldnéře lze charakterizovat jako fyzické osoby, které nejsou součástí žádné trvalé struktury a plní pouze konkrétní úkoly s vidinou rychlého obohacení. Oproti tomu SVBS jsou legálně založené právnické subjekty, které otevřeně prezentují svou podnikatelskou image, využívají mezinárodně uznávané právní a finanční nástroje, poskytují velmi širokou škálu odborných služeb a odmítají poskytovat své služby mezinárodním společenstvím neuznaným režimům (Brayton 2002: 305 a Beuns 2007: 4).

SVBS poskytují své služby rozličným aktérům: státům (armádám, bezpečnostním složkám jako např. americké armádě ve válce v Iráku či Afghánistánu) (Schwartz 2011), jiným soukromým společnostem (nap̌r. na ochranu ropovodů či polí s agáve) (Geneva Centre for the Democratic Control of Armed Forces 2004) nebo OSN pro její mírové operace (Jurriaans 2012; Buzatu a Buckland 2012; Ostensen 2009) či právě již zmiňovaným NGOs.

V tomto článku používám záměrně označení SVBS bez odlišení „bezpečnostních“ a „vojenských“ společností. Je to především z toho důvodu, že neexistuje konsenzus jak tyto společnosti přesně oddělit a často záleží na volbě názvu u jednotlivých autorů. Pokud bychom měli označení zobecnit, pak lze tyto společnosti rozlišit podle povahy poskytovaných služeb bezpečnostní společnosti se soustřed'ují více na taktické a strategické služby, zatímco vojenské společnosti na služby, které klientům pomáhají lépe fungovat ve válečném prostředí. Bezpečnostní společnosti poskytují služby, které jsou aplikovatelné i na jiná odvětví, a bývají menší než vojenské společnosti. Vojenské společnosti poskytují více ofensivní služby typu

\footnotetext{
2 Více výzkumných a právních definic (definiční problematika) viz Bureš a Nedědická (2011b).

${ }^{3}$ Poznámka autorky: či jiný statutární orgán podle platných zákonů dané země. Uvedená definice je založena na anglo-americkém právu.
} 
ozbrojených bojovníků, vojenského průzkumu, výcviku armády a policie či operací na osvobozování rukojmí, zatímco bezpečnostní společnosti poskytují zejména defensivní služby jako logistická podpora, odminování či ozbrojená ostraha. Nicméně toto odlišení je z hlediska praxe nefunkční, protože při působení společností v reálném prostředí často dochází k překrývání těchto služeb a společnost, která primárně může být označena jako „bezpečnostní,“ za určitých okolností může poskytovat služby „,vojenského“ charakteru (Ostensen 2009: 13-15).

U NGOs stejně jako u SVBS neexistuje v důsledku jejich rozmanitosti jednotná definice (Dupuy a Vierucci 2008: 13). NGOs jsou členy tzv. „třetího sektoru“ - tedy organizace, které nejsou součástí ani státního aparátu, ani komerční společnosti založené na výnosu. NGOs vznikly po 2. světové válce pod hlavičkou Organizace spojených národů (OSN) jako organizace nezávislé na vládách členských států OSN (Lewis 2007: 7). ${ }^{4}$ Přesto se významně zasazovaly o témata jako lidská práva, mír, životní prostředí či rozvoj. Zjednodušeně můžeme NGOs charakterizovat jako neziskové, dobrovolné občanské uskupení, organizované na lokální, národní nebo mezinárodní úrovni, které zároveň působí ve všech jmenovaných úrovních (Vedder 2007: 2). Tato definice je opravdu široká a zahrnuje v podstatě veškerá zájmová uskupení, která zdaleka nemusejí mít žádný vztah k SVBS (nap̌r. vzdělávací a zájmové kroužky).

Světová banka přijala vlastní definici NGOs, která vychází z definice „občanské společnosti“ (civil society): nevládni organizace a neziskové organizace, které jsou prítomné ve veřejném řivotè, vyjadruji zájmy a hodnoty svých členu či ostatnich, založené na etických, kulturnich, politickyich, védeckejch, náboženských nebo filantropických úvahách. Organizace občanské společnosti (CSOs) proto odkazuji k sirroké radè organizaci: komunitnim skupinám, nevládním organizacím (NGOs), odborovým organizacim, domorodým skupinám, charitativnim organizacím, organizacím založeným na vire, profesnim sdrǔ̌enim a nadacím (The World Bank web). Mnohem explicitnější definici poskytuje Úmluva Rady Evropy - Uznání právni subjektivity mezinárodnich nevládnich organizací. NGOs naplňují tyto podmínky: a) ve své zahraniční cinnosti json neziskové; b) byly ustaveny instrumentem podlébajicim vnitrostátnimu právu dané strany; c) svoji cünnost aktivné vykonávaji minimálnè ve dvou státech; d) mají své zastoupeni na územi dané strany a blavni správu/ reditelství na tomtéž územi ci na územi jiné strany (European Convention on the Recognition of the Legal Personality of International Non-Governmental Organisations 1986: Article 1).

V tomto článku se budu specificky zabývat těmi NGOs, které cílí především na poskytování humanitární pomoci a činnosti s tím souvisejících v teritoriálních oblastech a zemích, kde je zásadním způsobem narušena bezpečnost. Tyto NGOs se soustředí na následující sféry humanitární pomoci prevencí (před vznikem konfliktu), ochranou (udržením základního pořádku - ubytování, uprchlické kempy, odminováním), materiální pomocí (voda, potraviny, léky, oblečení, hygienické prostředky atd.), rekonstrukcí (peacebuildingem) (Alger 2005: 9).

Cílem tohoto článku je zodpovědět otázku, zda mohou být SVBS užity jako prostředek pro zajištění bezpečnosti a ochrany NGOs. Z pohledu výzkumu této problematiky využívání SVBS neziskovými organizacemi je potřeba zmínit, že ačkoliv $\mathrm{v}$ praxi se nejedná o něco zcela výjimečného, výzkum a literatura toto téma zatím nestihla dostatečně reflektovat (česká literatura o poznání méně než zahraničnî). V oblasti humanitárních operací existují materiály na využívání SVBS Organizací spojených národů (humanitární mise OSN a peacekeeping), nicméně v oblasti NGOs je literatura značně omezená. Často jsou také výzkumu vedeny se zaměřením na „humanitární pracovníky“ obecně, bez rozlišení, zda se jedná o př́slušníky OSN, či NGOs - je to

\footnotetext{
${ }^{4}$ Některé NGOs samožrejmě nebyly zcela nové. Např. Armáda spásy byla založena v Londýně již v roce 1865. Salvation Army web: http://www.salvationarmy.org/ihq/about.
} 
zejména z toho důvodu, že humanitární pracovníci procházejí stejnými podmínkami a problémy při provádění svých činností, bez ohledu na př́slušnost k organizaci. Na úrovni humanitární pomoci spolu také OSN a NGOs často spolupracují. Více jak $90 \%$ pomoci koordinované OSN je realizováno skrze NGOs (OSN poskytuje financování NGOs skrze své granty) (Lawry 2009).

\section{Vývoj NGOs, SVBS a jejich spolupráce}

NGOs, tak jak je známe dnes, vznikají v 19. století. Jednou z prvních NGOs byl Mezinárodní výbor Červeného kříže, ${ }^{5}$ založený v roce 1863 (International Committee of the Red Cross web). Ve 20. století se pak formují velké mezinárodní NGOs, jako nap̌r. Cooperative for American Remittances to Europe (CARE), založená v roce 1945 původně jako organizace pro pomoc válkou poničené Evropě (CARE International). Mnoho organizací bylo založeno pro jednu konkrétní oblast, ale od té doby svou působnost velmi rozšíríilo (Perito 2007: 102). Organizace InterAction, sdružující americké NGOs, uvádí, že více jak dvě třetiny NGOs byly založeny až po 60. letech 20. století, naprostá většina pak po roce 1975 (Perito 2007: 102).

Masivní vstup NGOs do mezinárodního prostředí ve smyslu jejich působení v humanitárních akcích lze vysledovat od období ukončení Studené války. Vstup těchto organizací do sféry mezinárodních vztahů je od této doby mnohem snazší, nejen kvưli politickému uvolnění po rozpadu Sovětského svazu, ale i díky zapojování soukromého a neziskového sektoru skrze prímé poptávky na dodávky specifických služeb od státu (Boemcken 2007: 260). NGOs se objevují také v souvislosti s vysokým nárůstem uprchlíků a vysídlených osob, které se často pohybují ve válečných zónách u hranic států (Perito 2007: 103). Narůstá počet etnických a náboženských konfliktů, které si vyžadují ochranu lidských práv, uprchlíků, humanitární pomoc a řešení konfliktů. Díky těmto faktorům rapidně narůstá počet NGOs. V červnu 1997 bylo uznáno zásadní postavení NGOs v oblasti udržitelného rozvoje v kapitole 27 Agendy 21, což vedlo k zintenzivnění poradního vztahu mezi OSN a NGOs (Lawry 2009: 26).

Unie mezinárodních sdružení (The Union of International Associations) ve své výroční knize uvádí, že v letech 2005-2006 bylo po celém světě registrováno kolem 38000 NGOs, což je dvojnásobek toho, kolik jich bylo v letech 1998-1999. Současný počet NGOs je 50x větší než v roce 1951 (Perito 2007: 101). Jejich př́tomnost v určitých misích závisí také na povědomí veřejnosti o daném problému (možnosti získat financování pro daný problém). Jako příklady jejich působení lze uvést Kosovo, kde Červený kř́žz, Mercy Corps a Oxfam zbudovaly v roce 1998 vlastní kancelář - více jak 150 NGOs se následně k této kanceláŕi přidružilo. Kolem 300 NGOs působilo na Srí Lance dva měsíce po ničivé vlně tsunami, která zemi zasáhla v roce 2004. Uzavírání smluv humanitárních aktérů se SVBS proběhlo téměř u každé válečné zóny - včetně Afghánistánu, Bosny, Demokratické republiky Kongo, Východním Timoru, Haiti, Iráku, Kosovu, Mosambiku, Sieře Leoně, Somálsku a Súdánu (Singer 2006: 68).

Podobným vývojem jako NGOs prochází také sféra SVBS. Ačkoliv se předchůdci moderních SVBS historicky objevují v různých obdobích, první „moderní společnosti vznikají ve 20. století. $^{6} \mathrm{~K}$ boomu SVBS dochází také po skončení Studené války. Důvodů je několik: proces odzbrojování a snižování počtu armádních př́islušníků je jeden z hlavních. Mnozí z propuštěných př́slušníků armád si tak hledali nové uplatnění, což vedlo přirozeně ke vzniku specializovaných společností, kde mohli své schopnosti uplatnit. Mnohé SVBS jsou prŕímo

\footnotetext{
${ }^{5}$ Dále v textu budu uvádět již pouze jako „Červený křížc.

${ }^{6}$ Více o historii a vývoji SVBS zde: Bureš a nedědická (2011a).
} 
zakládány bývalými vojáky (Avant 2004; Singer 2007; Singer 2005). Na druhé straně také klesaly výdaje na zbrojení, přičemž státy stále musely zabezpečovat základní funkce - bezpečnostní vakuum tak bylo vyplněno SVBS. Dalšími uváděnými důvody je např́ílad transformace povahy války, která postupně stírá rozdíly mezi civilisty a vojáky, rozvoj nových technologií, obecný trend k privatizaci a outsourcingu vládních funkcí ve snaze ušetřit finanční zdroje a zefektivnit činnost, či chaotičtější vývoj válek v rozvojovém světě, kde do konfliktů vstupují i dětští vojáci a státy se za těchto podmínek zdráhají do cizích konfliktů zasahovat (Avant 2004; Singer 2007; Singer 2005).

Posun směrem v uvažování NGOs nad zajištěním vlastní bezpečnosti nastal především na základě jejich zkušenosti s některými velmi náročnými misemi, které se staly „spouštěčem“ pro postupné zapojování soukromého sektoru k poskytování bezpečnostních služeb. V některých konfliktních zónách byly vystaveny natolik závažným a těžko řešitelným situacím, že tyto okolnosti vedly nejen k rozvoji konceptu jejich vlastní ochrany, ale především k úvahám (nakonec i realizaci) zapojení soukromého sektoru do řešení bezpečnosti. Jedním z nich byla mise v Somálsku, kde se snažily poskytovat pomoc v období sucha a hladomoru za podmínek neustálého zastrašování a nájezdů místních válečných vůdců. V zemi působilo třicet NGOs a mezi jednu ze zatěžkávacích zkoušek patřila spolupráce s armádou. Ačkoliv byla pomoc s posílením armády distribuována úspěšněji, docházelo ke střetu mentality NGOs a armády. Armáda dávala do prosazování bezpečnosti takovou razanci (Deborah D. Avant ji přirovnala k „zabíjení mouchy kladivem“) (Avant 2007: 147), že tím značně posílila nedůvěru ve spolupráci mezi NGOs a armádou. Mise v Somálsku také ovlivnila postoj k dárcovské pomoci - dárci se odvrátili od rozvojových programů a začali investovat do humanitární pomoci, která jim přšsla efektivnější. Následkem byl prudký vzrůst NGOs, které ale svou nepřipraveností a neznalostí ohrožovaly nejen svou vlastní bezpečnost. Jako pokus zabránit této situace u NGOs vydal Červený křriž v roce 1994 svůj etický kodex (Avant 2007: 147).

Další misí, která ovlivnila vývoj bezpečnosti NGOs, byla operace v Bosně. V zemi nebyla vůbec zajištěna bezpečnost, a tak někteři začali pochybovat o smyslu humanitární pomoci, když jejím výsledkem byli pouze „dobře nakrmení mrtvi““ (Keen 2008: 118). Mise ve Rwandě pro změnu umožnila válečným zločincům dostat se díky humanitární pomoci mezi uprchlíky, a pomoct tak exilové vládě získat prostředky, aby mohla být obnovena v Zairu (Keen 2008: 118; Avant 2007: 147-148). Masakr šesti pracovníků Červeného křriže v Čečensku zase ukázal, že pasivní přijetí není dostatečnou zárukou bezpečnosti (Keen 2008: 118; Avant 2007: 147-148).

Změny přinesla i situace po teroristických útocích z 11. záŕí 2001, kdy se pro NGOs prohloubily hrozby v podobě terorismu a náboženského extremismu (Perito 2007: 103-104). V Afghánistánu a Iráku islámští teroristé běžně cílí na vojáky a pracovníky humanitárních organizací. Časté únosy a vraždy zaměstnanců vedly NGOs k většímu zapojení lokálních pracovníků či stažení misí do sousedních zemí. Vzrůst nepokojů a incidentů v Afghánistánu a Iráku odradil velké množství NGOs, a část se jich proto přemístila do Jordánska či stáhla svou misi úplně (Perito 2007: 105).

Po 11. záŕí 2001 se čím dál tím častěji objevují názory, že humanitární pomoc je „pěknou tváří nového kolonialismu“ (Fassin a Pandolfi 2012: 41). Ve většině případů totiž směruje z bohatých Západních zemí do chudých rozvojových zemí. Protože chudoba je také často

\footnotetext{
7 Základem se stává morální imperativ zasáhnout do humanitární krize, bez ohledu na politické okolnosti - tak jak ji původně v 70. letech 20. století prosazovala organizace Lékaři bez hranic. The International Committee of the Red Cross web, „Code of Conduct, “http://www.ifrc.org/en/publications-and-reports/code-of-conduct/.
} 
považována za hlavní prŕčinu terorismu, je kladen velký důraz na rozvojovou pomoc zprostředkovanou humanitárními organizacemi. Popisovaná situace získala obzvláště negativní nálepku v posledních více jak 10 letech. V říjnu 2003 proto např́klad Mullah Omar ${ }^{8}$ odsoudil humanitární organizace včetně NGOs s tím, že jsou to „nejhorší nepřátelé Islámu“ (Atassi 2012). V listopadu 2011 pro změnu islámská organizace aš-Šabáb ${ }^{9}$ zakázala 16 agentur OSN a mezinárodních NGOs působících v Somálsku s obviněním, že obhajují sekularismus a nejsou dostatečně nestranné (Margesson, Dagne a Hanrahan 2012: 3 a 17).

Všechny tyto momenty postupně posilovaly jednak přehodnocení konceptu bezpečnosti NGOs a podpoŕily snahu o ochranu jejich zaměstnanců; zároveň dovedly NGOs jak k úvahám, tak k reálnému využívání služeb SVBS jako jednu z alternativ zajištění bezpečnosti. Využívání SVBS pro humanitární účely (potažmo NGOs) je bezpochyby ovlivněno spoluprací SVBS s OSN. OSN začalo SVBS využívat od roku 1990. SVBS nejsou užívány jako peacekeepingové síly na předních liniích, ale místo toho spolupracují na řadě jiných podpůrných úkolů OSN (Ghebali 2008: 213-230; Isenberg 2009; Singer 2003): kromě zajištění bezpečnosti poskytují např́klad poradenství, výcvik, odminování, logistiku a další (Ostensen 2012: 11). OSN si najímá SVBS pro řadu svých agentur, programů, fondů a oddělení; mezi pravidelné zákazníky patří Dětský fond OSN (UN Children Fund, UNICEF), Světový potravinový program (World Food Programme, WPF) a Rozvojový program (UN Development Programme, UNDP) (Avant 2004: 7). Podle Deborah D. Avant by OSN v 90. letech 20. století nebyla schopna realizovat své operace bez pomoci SVBS (Avant 2004: 7). OSN má schváleno již nejméně jedenáct SVBS pro dodávku služeb (Ostensen 2009: 42). Pro ukázku toho, jak vypadá využívání SVBS ze strany OSN, níže uvádím tabulku shrnující rozložení služeb pro jednotlivé mise a společnosti, které nejčastěji dodávají služby. OSN také v největší míře přiděluje zakázky těm společnostem, které nenabízejí ofensivní služby - velmi oblíbený je např́klad ArmorGroup ${ }^{10}$, který je také hodně využíván NGOs. ArmorGroup podle slov svého obchodního ředitele neměl zájem podílet se na misi OSN v Konžské demokratické republice (United Nations Organization Mission in the Democratic Republic of Congo, MONUC), protože návrh mise shledával přiliš kontroverzním - v návrhu bylo zahrnuto i užití síly v ofensivním smyslu (Ostensen 2009: 93-94).

\footnotetext{
${ }^{8}$ Mullah Omar je vůdcem Talibánu. USA na něj vypsaly odměnu ve výši 10 milionů USD za tip k jeho dopadení. Předpokládá se, že se ukrývá v Pákistánu. (Rewards for Justice; Coll 2012; Abiew 2003: 31-32).

${ }^{9}$ Jedná se o militantní somálskou islámskou organizaci, která se přidala k al-Kajdě (BBC News).

${ }^{10}$ Bývalá společnost Defense Systems Limited (DSL). V roce 2008 byl ArmorGroup koupen britskou společností G4S (The Independent 2008).
} 
Tab. č. 1: Kontrakty OSN se SVBS

\begin{tabular}{|c|c|c|c|}
\hline Zakázka společnosti, země, rok & $\begin{array}{l}\text { Podpůrné } \\
\text { funkce }\end{array}$ & $\begin{array}{l}\text { Poskytová } \\
\text { ní } \\
\text { bezpečnost } \\
\text { i }\end{array}$ & $\begin{array}{c}\text { Expertní } \\
\text { služby }\end{array}$ \\
\hline 1. DSL na Balkáně 1992 & $\mathrm{X}$ & $\mathrm{X}$ & \\
\hline 2. DSL v Somálsku & & $\mathrm{X}$ & \\
\hline 3. DSL v Angole & & $\mathrm{X}$ & \\
\hline 4. DSL v Súdánu & & $\mathrm{X}$ & \\
\hline 5. DSL v Mosambiku, pravděpodobně 1995 & $\mathrm{X}$ & & \\
\hline 6. EO v Sieře Leone 1996-97 & & $\mathrm{X}$ & \\
\hline 7. DSL v Angole & $\mathrm{X}$ & $\mathrm{X}$ & \\
\hline 8. DSL v Afghánistánu & & $\mathrm{X}$ & \\
\hline 9. ICI of Oregon v Libérii v polovině 90 . let & $\mathrm{X}$ & & \\
\hline 10. ICI of Oregon na Haiti 1996 & $\mathrm{X}$ & $\mathrm{X}$ & $\mathrm{X}$ \\
\hline 11. ArmorGroup v Bosně 1996 a dále & & & $\mathrm{X}$ \\
\hline 12. Lifeguard v Sierra Leone 1998 & $\mathrm{X}$ & & \\
\hline 13. DynCorp v Angole 1998 & $\mathrm{X}$ & & \\
\hline 14. DynCorp v Bosně na začátku 90. let & & & $\mathrm{X}$ \\
\hline 15. DSL v Sieře Leone 1998 & & $\mathrm{X}$ & \\
\hline 16. DynCorp na Východním Timoru 1999 & $\mathrm{X}$ & & \\
\hline 17. DynCorp v Sierra Leone 2000 & $\mathrm{X}$ & & \\
\hline 18. PAE v Sierra Leone 2000 & $\mathrm{X}$ & & \\
\hline 19. DSL v Kosovu 2001 & $\mathrm{X}$ & & $\mathrm{X}$ \\
\hline 20. PAE v Demokratické republice Kongo 2001 & & & $\mathrm{X}$ \\
\hline 21. PAE na Východním Timoru 2001 & $\mathrm{X}$ & & \\
\hline 22. GD4 v Kosovu & $\mathrm{X}$ & & \\
\hline 23. Kroll Ass. v Angole 2001 & & & $\mathrm{X}$ \\
\hline 24. ArmorGroup v Demokratické republice Kongo & $\mathrm{X}$ & $\mathrm{X}$ & \\
\hline 25. KZN Security na Východním Timoru 2001 & & & $\mathrm{X}$ \\
\hline $\begin{array}{l}\text { 26. Empowerement Loss Control na Východním Timoru } \\
2001\end{array}$ & & & $\mathrm{X}$ \\
\hline 27. PAE v Demokratické republice Kongo 2004 & $\mathrm{X}$ & & \\
\hline 28. PAE na Pobřeží slonoviny 2004 & $\mathrm{X}$ & & \\
\hline 29. Global Strategies Group v Iráku 2004 & & $\mathrm{X}$ & \\
\hline 30. Global Strategies Group v Afghánistánu 2004 & $\mathrm{X}$ & $\mathrm{X}$ & $\mathrm{X}$ \\
\hline 31. ArmorGroup na Kypru 2004 a dále & & & $\mathrm{X}$ \\
\hline 32. ArmorGroup v Iráku 2005 & & & \\
\hline
\end{tabular}

Zdroj: Ostensen 2009: 43. 
Graf 1: Rozdělení kontraktů mezi dodavatele OSN

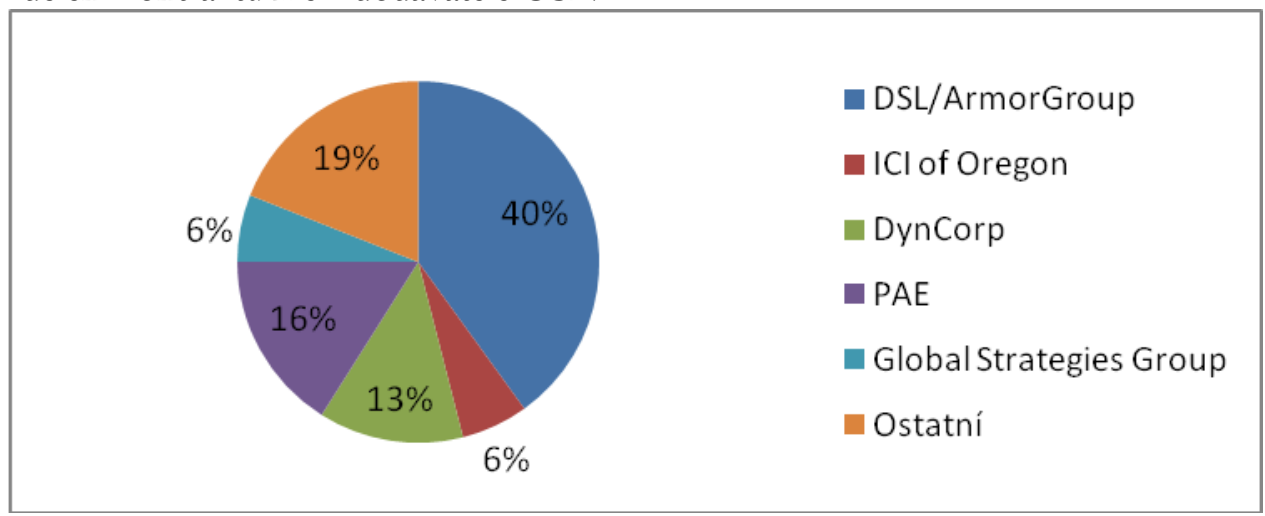

Zdroj: Ostensen 2009: 94.

Dnes již můžeme hovořit o tom, že NGOs nejsou z pohledu své bezpečnosti pasivní, ale aktivně vyhledávají možnosti, jak zajistit pro své zaměstnance ochranu. Vliv na to má celá řada okolností, včetně některých negativních zkušeností uvedených výše. NGOs se nebojí využívat ani odstrašující (deterrance) metody bezpečnosti (jak bude popsáno níže), které zahrnují i ozbrojenou ostrahu. ${ }^{11}$ Dochází tak k větší „militarizaci“ pomoci ve smyslu zvýšení bezpečnosti, bud’: skerze armádu, v nǐ̌ jsou vojáci ze Západu zapojeni do společné pomoci a rekonstrukéního úsili spolu sodborníky z.ivilnich rozvojových a bumanitámich organizaci (...), [nebo] skrže ne-státni oblast, kde personál bumanitárních organizaci spolupracuje se soukromými beapečnostnimi společnostmi (Boemcken 2007: 26). Zajímavé je, že například organizace Červeného kříže veřejně odsoudila použivání odstrašujících taktik s tím, že si zakládá na nestrannosti, neutralitě a nezávislosti, a spolupráce s vojenskou silou ve formě armády tak nepřichází v úvahu (více informací o této problematice v odstavcích o alternativách bezpečnosti pro NGOs). Nicméně dnes již svůj postoj na základě zkušeností z praxe značně korigovala a např́ílad k SVBS je mnohem shovívavější. V roce 2004 ve svém prohlášení Červený kř́ž napsal: $A$ ž do ted' byly kontakty mez̧i ICRC $C^{12}$ a soukromými vojenskými a bezpečnostnimi společnostmi na neformálni bázi (...) ICRC plánuje systematičtějsǐ př̀stup zamèrený na společnosti puisobici v konfliktnich situacich nebo poskytujicich školení pro ozbrojené síly (International Committee of the Red Cross 2004).

\section{Motivace NGOs pro využívání SVBS}

Využívání SVBS je mezi NGOs stále rozšîréenější, i když rozhodně nemůžeme mluvit o masovém trendu. Hlavním faktorem pro rozhodnutí NGO najmout si SVBS je především to, že NGOs jsou velmi často nuceny pracovat $v$ nebezpečných oblastech (Lilly 2000: 18). Kanadská odnož organizace CARE např́klad uvedla, že základním problémem všech NGOs je právě bezpečnostní vakuum vyvolané mimořádnou situací, v níž se pomoc odehrává a neochota mezinárodních sil

\footnotetext{
${ }^{11}$ Založeno na tzv. „bezpečnostním trojúhelníku“, který se skládá ze tří základních strategií bezpečnosti: přijetí (acceptance), ochrana (protection) a odstrašení (deterrence), přičemž ochrana může být vnímána jako pasivní/měkký model bezpečnosti a odstrašení aktivní/tvrdý model bezpečnosti. $\mathrm{V}$ ideálním případě by se měly doplňovat všechny tři metody navzájem. Mezi pasivní metody patří přesvědčování, že nemá smysl poškozovat NGO, a přizpůsobení se lokálním podmínkám. Mezi ochranné metody patři obrana proti prúípadnému útoku či znesnadnění útoku pomocí výcviku a pasivních opatření typu oplocení či nošení neprůstřelných vest. Odstrašující metody tvoří přímá obrana proti útoku, např́lklad pomocí ozbrojených stráží, spolupráce s armádou. (Boemcken 2007; Avant 2007; The UN Refugee Agency).

12 Poznámka autorky: The International Committee of the Red Cross, Mezinárodní výbor červeného kříže.
} 
postihovat a řešit problémy bezpečnosti (Lilly 2000: 18). Násilné výpady vůči pracovníkům poskytujícím pomoc navíc narůstají.

Tab. č. 2: Hlášené větši násilné incidenty cílené proti humanitárním pracovníkům

\begin{tabular}{|l|r|r|r|r|r|r|r|r|r|r|r|r|}
\hline & 1997 & $\mathbf{1 9 9 8}$ & $\mathbf{1 9 9 9}$ & $\mathbf{2 0 0 0}$ & $\mathbf{2 0 0 1}$ & $\mathbf{2 0 0 2}$ & $\mathbf{2 0 0 3}$ & $\mathbf{2 0 0 4}$ & $\mathbf{2 0 0 5}$ & $\mathbf{2 0 0 6}$ & $\mathbf{2 0 0 7}$ & $\begin{array}{l}\text { Celke } \\
\text { m }\end{array}$ \\
\hline $\begin{array}{l}\text { Počet } \\
\text { incidentů }\end{array}$ & 35 & 27 & 32 & 42 & 29 & 46 & 63 & 63 & 76 & 95 & 82 & 590 \\
\hline Počet obétí & 73 & 69 & 65 & 91 & 90 & 85 & 143 & 125 & 185 & 222 & 162 & 1310 \\
\hline $\begin{array}{l}\text { Mezinárod } \\
\text { ní }\end{array}$ & 33 & 17 & 25 & 21 & 28 & 17 & 27 & 24 & 34 & 24 & 48 & 298 \\
\hline Národní & 40 & 52 & 40 & 70 & 62 & 68 & 116 & 101 & 151 & 198 & 114 & 1012 \\
\hline Zabito & 39 & 36 & 30 & 57 & 27 & 38 & 87 & 56 & 54 & 85 & 55 & 564 \\
\hline Zraněno & 6 & 15 & 15 & 23 & 20 & 23 & 49 & 46 & 95 & 81 & 57 & 430 \\
\hline Uneseno & 28 & 18 & 20 & 11 & 43 & 24 & 7 & 23 & 36 & 56 & 50 & 316 \\
\hline OSN & 22 & 24 & 17 & 31 & 28 & 17 & 31 & 11 & 48 & 61 & 51 & 341 \\
\hline ICRC & 9 & 26 & 7 & 9 & 11 & 7 & 8 & 1 & 3 & 10 & 4 & 95 \\
\hline IFRC & 10 & 5 & 4 & & 3 & 5 & 20 & 11 & 5 & 17 & 8 & 88 \\
\hline NGOs & 31 & 14 & 37 & 49 & 48 & 55 & 84 & 98 & 127 & 128 & 81 & 752 \\
\hline
\end{tabular}

ICRC $=$ The International Committee of the Red Cross

IFRC $=$ The International Federation of the Red Cross and Red Crescent Societies

Zdroj: Stoddard, Harmer a DiDomenico 2008: 7.

Graf 2: Vývoj počtu útoků vưči humanitárním pracovníkům

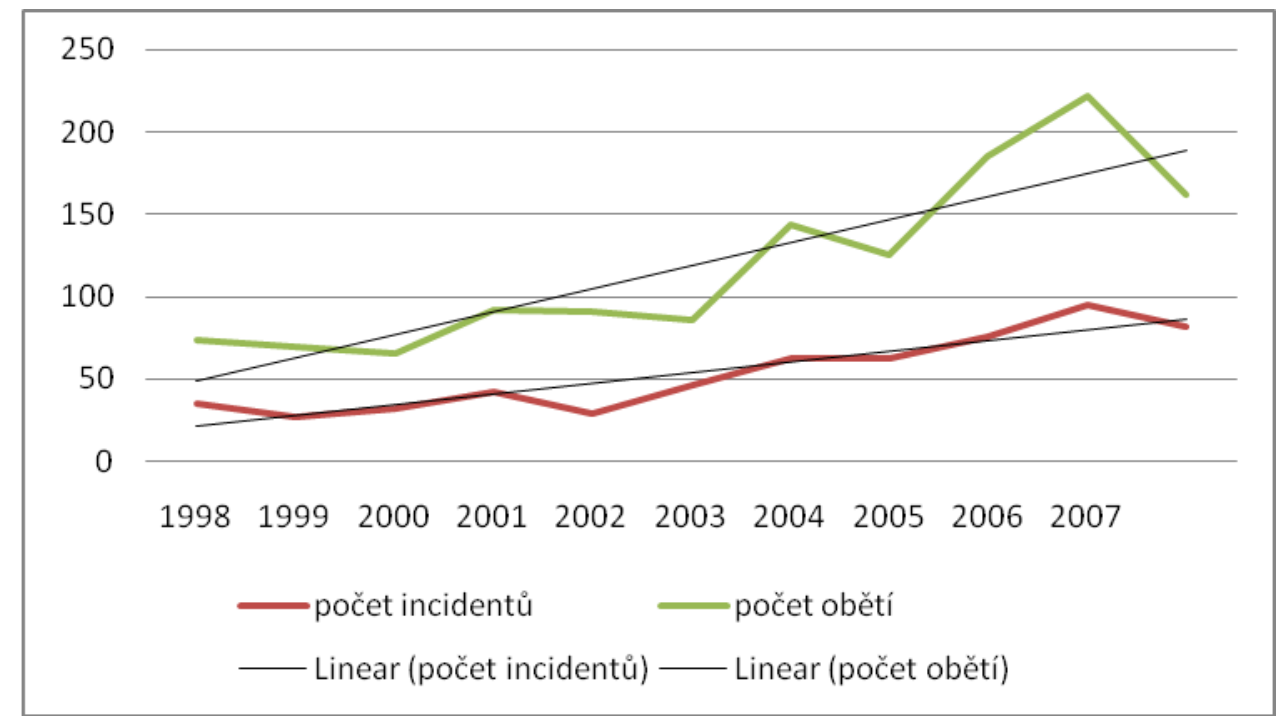

Vytvořeno $z$ dat $z$ tabulky 2 . 
Mezi humanitárními pracovníky právě na NGOs připadá nejvíce obětí násilí.

Graf 3: Úmrtí humanitárních pracovníků podle typu instituce

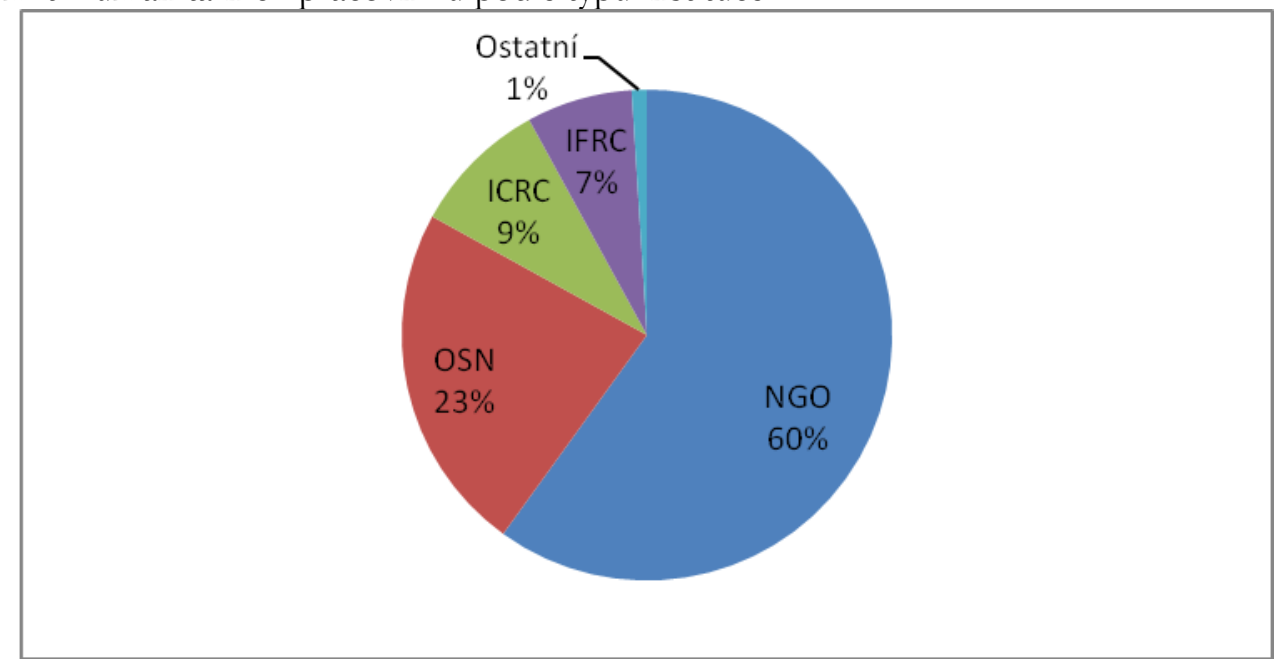

Zdroj: Stoddard, Harmer a Haver 2006: 12.

V červnu 2004 organizace Lékaři bez hranic zcela ukončila misi v Afghánistánu poté, co bylo pět jejích pracovníku zabito při útoku. Jen čtyři měsíce nato byl britský ředitel organizace CARE unesen v Iráku a popraven, což vedlo ke stažení CARE i Lékařů bez hranic z této země. Ve stejném měsíci vozidlo organizace Save the Children najelo na minu v severním Dárfúru, v Súdánu - zahynuli zde 2 pracovníci organizace (Boemcken 2007: 259). Takto bychom ve výčtu incidentů mohli pokračovat dále. V souvislosti s násilnými útoky v 90. letech 20. století zahynulo dokonce více pracovníků Červeného křiže než př́slušníků armády Spojených států amerických (USA) (Singer 2007: 184). Mezi lety 1997 a 2001 zemřelo nejvíce humanitárních pracovníků právě v souvislosti s různými útoky (King 2002).

Tabulka 3: Úmrtí humanitárních pracovníků podle typu incidentu

\begin{tabular}{|c|c|c|c|c|c|c|c|}
\hline Rok & $\begin{array}{c}\text { Přepaden } \\
\text { í vozidla } \\
\text { či } \\
\text { konvoje }\end{array}$ & $\begin{array}{c}\text { Stacionár } \\
\text { ní útok }\end{array}$ & $\begin{array}{c}\text { Protiletadlo } \\
\text { vá palba }\end{array}$ & $\begin{array}{c}\text { Bombardová } \\
\text { ní }\end{array}$ & $\begin{array}{c}\text { Minová } \\
\text { pole }\end{array}$ & $\begin{array}{c}\text { Nehoda } \\
\text { při } \\
\text { přepravě }\end{array}$ & Celkem \\
\hline $\mathbf{2 0 0 1}$ & 10 & 8 & 1 & 4 & 4 & 12 & 39 \\
\hline $\mathbf{2 0 0 0}$ & 29 & 12 & - & 2 & 5 & - & 48 \\
\hline $\mathbf{1 9 9 9}$ & 15 & 12 & 9 & 1 & - & 27 & 64 \\
\hline $\mathbf{1 9 9 8}$ & 13 & 11 & 14 & 3 & 1 & 8 & 50 \\
\hline $\mathbf{1 9 9 7}$ & 14 & 12 & - & - & - & 22 & 48 \\
\hline
\end{tabular}

Zdroj: King 2002.

Poptávka po bezpečnostních službách pro humanitární účely se přirozeně zvyšuje, což je důsledkem rostoucího násilí (Mandel 2001: 129-151). NGOs se často nemohou spolehnout na ochranu zajištěnou státem. Svou roli $v$ tom může hrát i distribuce zbraní a jejich snadná dostupnost pro různé aktéry. Od 90. let 20. století je to poprvé od vzniku „národních státư “‘13, kdy je daleko více zbraní alokováno v rukou soukromých entit, nikoliv státu. Těmito subjekty

\footnotetext{
${ }^{13}$ Národní státy utvořené po Vestfálském míru.
} 
nejsou pouze SVBS, ale také různé paravojenské organizace, organizované zločinné skupiny, klasičtí žoldnéři či různé soukromé milice - a samozřejmě i běžní civilisté. Státům sice zůstávají $\mathrm{v}$ rukou velké zbraně s vysokou účinností, nicméně malé konvenční zbraně ${ }^{14}$ jsou dnes hromadně ve vlastnictví soukromých subjektů. Velkou měrou se na tom podílí rozpad Sovětského bloku, kdy byly přebytečné zásoby zbraní těmito subjekty rozebrány (Anders 2007). Přbližně 875 milionu malých zbraní je v obèhu po celém svètè a pouze jedna tretina je v rukou legálnè utvořených bespečnostnich sil. (...) 200 milionu patř státnim armádám a 26 milionu ù více agenturám vymábajicim dodř̌ování práva. ${ }^{15}$ Vètšina celosvêtorých zásob zbrani - necelé dvě trétiny z.odhadovanébo celku - jsou ovšem v rukou nestátnich aktéru a civilistů (Stohl a Hogendoom 2012: 1 a 5). Ve výzkumu Cate Buchanan a Roberta Muggaheho z roku 2005 provedeném mezi humanitárními pracovníky (zahrnující mimo jiné organizace jako CARE, Červený křižz, či Oxfam) téměř 1 z 5 dotazovaných odpověděl, že byl obětí „,bezpečnostního incidentu“ při provádění svých činností (např. útoku, loupeže, zastrašování, harassementu, únosu, sexuálního násilî) šest měsíců před tím, než byl dotazován v rámci výzkumu. Jedna třetina respondentů, která byla obětí incidentu, navíc uvedla, že byla ohrožována zbraní (Buchanan a Muggah 2005: 23). Dalším prŕíkladem může být Afghánistán (jedna z nejnebezpečnějších oblastí pro NGOs a humanitární pracovníky obecně) (Stoddard, Harmer a Haver 2011: 3), kde bylo každým rokem provedeno několik útoků na NGOs ozbrojenými opozičními silami. Některé útoky v Afghánistánu jsou navíc prováděny i běžnými zločinci a také zahrnují užití zbraně.

Graf 4: Útoky ozbrojených opozičních sil na NGOs v Afghánistánu

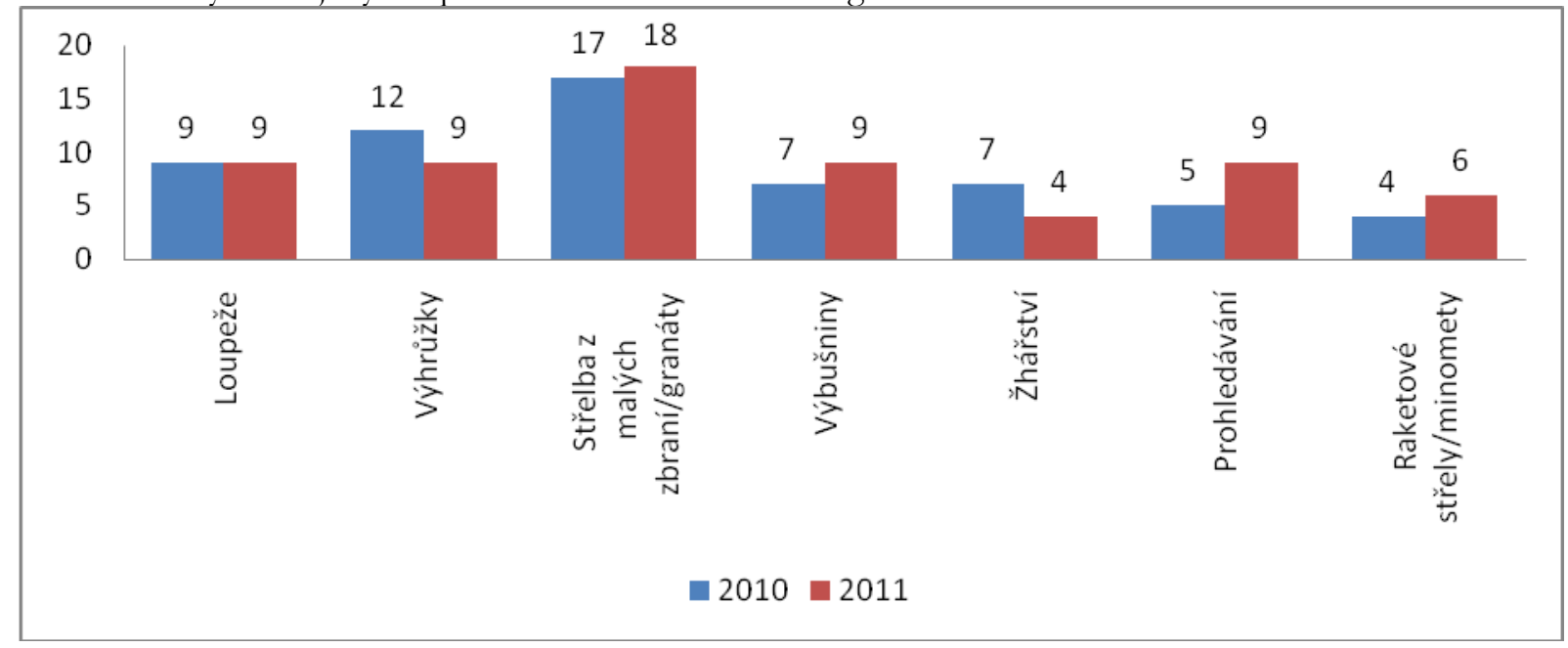

Zdroj: ANSO Quarterly Data Report 2011: 5.

\footnotetext{
14 Pušky, pistole, revolvery, samopaly, lehké kulomety apod.

${ }_{15}$ Poznámka autorky: myšlena je např́klad policie, vězeňská ostraha či různé specializované agentury typu FBI a CIA.
} 
Graf 5: Kriminální útoky vưči NGOs v Afghánistánu

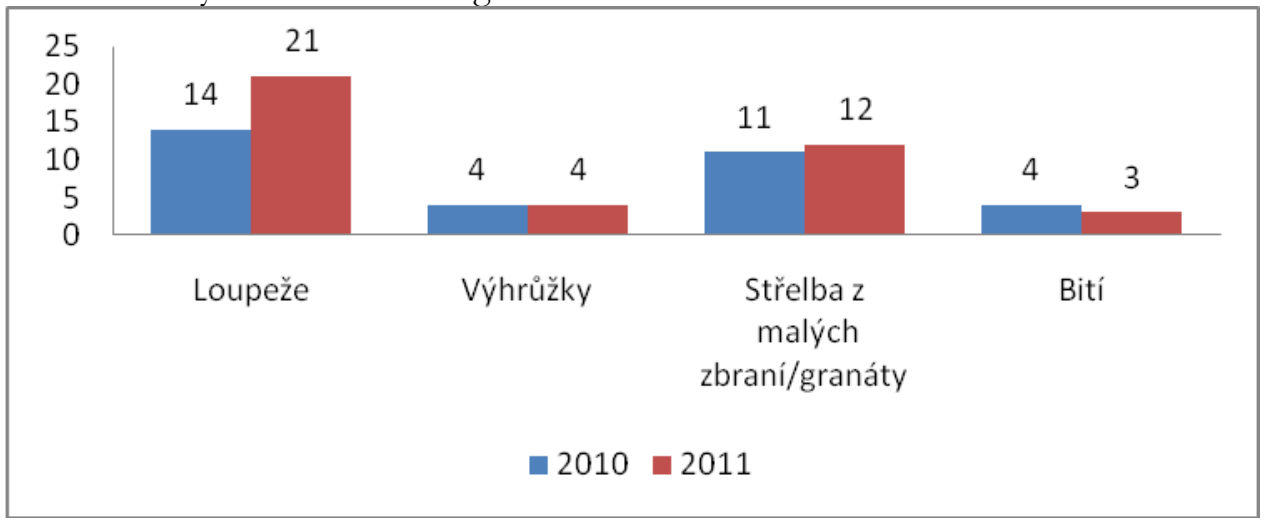

Zdroj: ANSO Quarterly Data Report 2011: 5.

Většina úmrtí spojených s konflikty je obecně způsobena právě malými zbraněmi, které jsou často nazývány „zbraněmi hromadného ničení pro chudé“ (Wallacher a Harang 2011: 2). Kromě jiného prokazatelně stojí za vzrůstem úmrtí zaměstnanců OSN a peecekeepingových sil, stejně tak jako osob z NGOs (United Nations Office for Disarmament Affairs). Pokud tedy NGOs postaví svou strategii pouze na „pasivním přijetí“ v oblasti, kde je vysoký výskyt zbraní mezi populací a různými ozbrojenými skupinami, pak je pro ni velmi těžké zajistit svým zaměstnancům ochranu. Jako jedna z možností se proto jeví využití ozbrojené ochrany dodávané některou společností (a tedy zapojení „odstrašovacího“ modelu bezpečnosti).

Dalším motivem pro NGOs k tomu, proč využívat SVBS, je například celková bezpečnostní situace v Africe. Války jsou zde ve velké míře vnitrostátní (občanské), bez jasného vymezení válečných hranic, kde se běžní civilisté stávají cíli útoků (Abiew 2003: 32). Slabé africké státy za podmínek složitých občanských válek bez jasného vymezení bojujících stran nemají dostatek donucovacích prostředků, aby byly schopny zajistit bezpečnost (The Fund for Peace) ${ }^{16}$. Pro NGOs tak často ani nezbývá jiná volba, než využít pomoci SVBS (Wodarg 2008: 7). Např́klad v Somálsku v roce 1991 se z důvodu nedostatečné ochrany velké množství těchto organizací spojilo s různými ozbrojenými skupinami (Boemcken 2007: 260). Pro západní Afriku ${ }^{17}$ je pro změnu specifické, že státy v podstatě nikdy neměly monopol na legitimní sílu. V západní Africe působilo několik dichotomizovaných režimů a bezpečnostní sektor byl charakteristický pro svoji rozdvojenost na formální a neformální. Zatímco statutární bezpečnostní instituce zajišt’ovaly bezpečnost státu a jeho institucí, velké množství obyvatel spoléhalo na paralelní, méně formální bezpečnostní struktury. Ti, kteří měli/mají prostředky (velké firmy a bohatí jednotlivci), si služby kupují u soukromých společností. Bezpečnostní instituce v západní Africe jsou sice legální, ale ne legitimní (Ebo 2008: 144). Na základě toho se např́klad v Nigérii rozrostl podnikatelský sektor se soukromou bezpečností. Je odhadováno, že v Nigérii působí okolo 1500 - 2000 SVBS, zaměstnávajících přes 100000 osob. Bezpečnost je pro zemi druhým největším zdrojem př́jmu po ropě a plynu (Ebo 2008: 147-148).

\footnotetext{
${ }^{16}$ Podle indexu organizace The Fund for Peace je největší množství tzv. „zhroucených států“ (failed states) právě $\mathrm{v}$ Africe (The Fund for Peace).

17 Země západní Afriky: Benin, Burkina Faso, Gambie, Ghana, Guinea, Guinea-Bissau, Kapverdské ostrovy, Libérie, Mali, Mauritánie, Niger, Nigérie, Pobřeží slonoviny, Senegal, Sierra Leone, Togo. Z hlediska geografie sem patř́ i Kanárské ostrovy, které ale náleži Španělsku.
} 
Důležitým faktorem také je, že kontrola zdrojů v ozbrojených konfliktech je jednou z hlavních priorit bojujících skupin. Čím více prostředků mají, tím lépe se jim pokračuje v boji $\mathrm{s}$ neprŕitelem. NGOs často disponují cennými komoditami a jsou z tohoto důvodu vyhledávaným terčem (Deschamps 2005: 35). Podle zprávy kontrolního úřadu USA (United States Government Accountability Office) z roku 2006 zaměřené na humanitární pomoc v Dárfúru bylo přepadávání konvojů NGOs velmi běžné. Mezinárodní rozvojová agentura Spojených států (United States Agency for International Development, USAID) a představitelé OSN podávali zprávy o tom, že při tomto přepadávání jsou nejčastěji kradena vozidla, finanční hotovost, potraviny a další humanitární pomoc. Nicméně samotné NGOs udávaly, že nejvíce se kradlo komunikační zařízení a vozidla samotná spíše než humanitární pomoc. V té době působilo v Darfúru 86 NGOs (United States Government Accountability Office 2006). V roce 2008 v Afghánistánu bylo přepadeno nebo vypleněno 40 humanitárních konvojů a 47 podpůrných zařízení s humanitární pomocí (Jelinek 2009). V Somálsku a Súdánu NGOs hlásily, že více jak $80 \%$ potravinových dodávek bylo ztraceno v důsledku zpronevěry či krádeže (Abiew 2003: 27). Několik organizací ve Rwandě se pro změnu snažilo získat kontrolu nad procesem pomoci, s kterou bylo různě manipulováno Rwandskými ozbrojenými silami a vládou. To vyústilo v násilnou reakci proti humanitárním pracovníkům. 35 zaměstnanců CARE (Rwand’anů najatých na kontrolu vstupu do kempu a řízení dopravy) bylo zabito poté, co CARE zemi opustila ze strachu z výhrůžek zabitím (Avant 2004: 202). Reakce na krádeže pomoci se např́č NGOs liší, někdy mohou být zdrojem dalšího napětí. NGOs tuto situaci proto často nechtěji ř rešit nijak radikálně („stř́let lidi za to, že sebrali potraviny" Byman 2011: 99), ale raději přijmou fakt, že část jejich pomoci připadne bojujícím stranám (Byman 2011).

Neschopnost zajistit bezpečnost pro své zaměstnance a činnosti, stejně jako své materiální zázemí a zařízení, vedla NGOs k obratu k SVBS a jejich službám. „Humanitární ,průmysl‘ již prošel masivní privatizací, kdy soukromé společnosti dnes poskytují velkou logistickou podporu v humanitárních operacích“ (Lilly 2000: 19). Přesto jsou důsledky dopadu využívání SVBS na humanitární operace a potenciální dopady na lokální konflikty nejasné a je potřeba je důsledněji zkoumat.

\section{Spolupráce NGOs a SVBS v praxi}

V posledních letech využívání služeb SVBS u humanitárních organizací - tedy nejen NGOs, ale i OSN - obecně vzrůstá. Nejčastěji se vyskytuje u zemí, kde právě probíhá konflikt, nebo tam, kde konflikt právě skončil. Většina humanitárních pracovníků se shoduje na tom, že nasmlouvání určitých bezpečnostních služeb od externích specialistů není nic výjimečného. Přesto ale využívání oz̧brojené soukromé ochrany je spíše ojedinělé a velmi záleží na daném kontextu, kde jsou tyto služby využívány (Stoddard, Harmer a DiDomenico 2009: 10).

Ze všech různých typů služeb dodávaných SVBS jsou ozbrojené služby až na posledním místě. Některé NGOs dokonce uvádějí, že jejich jediné využití ozbrojené ochrany se odehrálo v kontextu operací v Centrální Americe, kde tato praktika byla př́mo vyžadována lokální bezpečnostní kulturou - pokud by zbraně NGO neměla vůbec k dispozici, okamžitě by se stala terčem útoku. Ve stejném výzkumu od Abby Stoddard, Adele Harmer a Victorie DiDomenico bylo doloženo, že $22 \%$ subjektů potvrdilo využívání ozbrojených SVBS (Stoddard, Harmer a DiDomenico 2009: 19). Zároveň výzkum prrinesl informace o využití typu SVBS: 61 \% subjektů potvrdilo využívání lokálních společností, zatímco $35 \%$ za stejné období potvrdilo využívání mezinárodních firem. Když byly využívány mezinárodní SVBS, pak nejčastějšími službami byl 
bezpečnostní výcvik pro zaměstnance, poradenství voblasti řízení a posouzení rizik (risk assessment) (Mears 2009: 5; Stoddard, Harmer a DiDomenico 2009: 19). Zajímavostí je, že na poli humanitárních operací ostraha zařízení a bezpečnostní výcvik jsou užívány spiše OSN, kdežto vyhodnocení rizik a bezpečnostní rízení spíše NGOs. Mưže to být zaprýíčněno tím, že kapacity OSN jsou obecně mnohem větší a z tohoto důvodu si vyžadují více fyzické ostrahy. Některé organizace také udávají, že na tyto služby využívají armádu hostitelské země, lokální milice či ozbrojené skupiny a mírové jednotky (Stoddard, Harmer a DiDomenico 2009: 19).

Čím více je prostř̌edí nebezpečnější a existuje více rizik, tím spiše se NGOs obracejí na velké korporátní SVBS, které mají na rozdíl od lokálních společností dostatek zkušeností (Boemcken 2007: 24). G4S např́klad poskytuje své služby NGOs působícím v Keni (G4S). Securitas zase pro změnu v roce 2011 poskytovala ostrahu NGOs na Srí Lance (Securitas 2011).

Graf 6: Služby užívané NGOs a poskytované SVBS

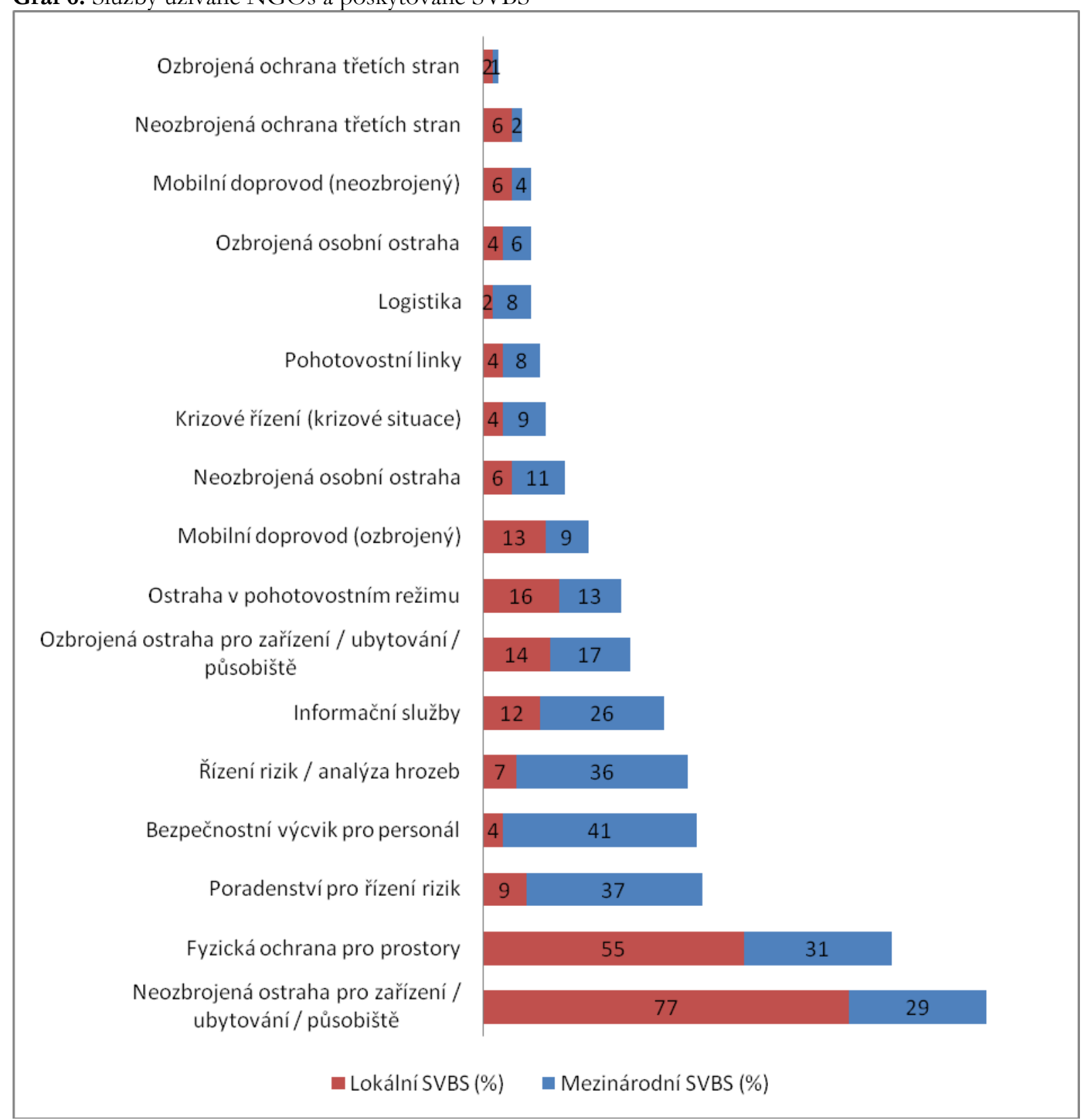

Zdroj: Stoddard, Harmer a DiDomenico 2009: 10. 
$\mathrm{Na}$ to, zda jsou využívány ozbrojené SVBS na ochranu humanitárních pracovníků, má jednoznačně velký vliv bezprostřední bezpečnostní situace v hostitelské zemi. Vyšší procento ozbrojených SVBS je využito např́klad v Dárfúru či v Iráku, kde jsou oproti jiným státům velmi vysoká bezpečnostní rizika (Stoddard, Harmer a DiDomenico 2009: 9). Okupace Iráku a Afghánistánu také posílila vazby mezi NGOs a SVBS. V roce 2006 se předpokládalo, že $25 \%$ „top“ firem poskytovalo v Iráku a Afghánistánu humanitárním klientům ozbrojenou ochranu, zatímco 50 \% poskytovalo podporu v logistických službách (Engler 2010).

\section{Existence alternativ bezpečnosti NGOs}

Výše v článku jsem zmínila motivy pro využívání SVBS a zároveň se pokusila nastínit jejich spolupráci s NGOs. Nicméně, každého čtenáře jistě napadne, zda neexistují i další alternativy pro zajištění bezpečnosti operujících NGOs. Naprosto samozřejmým aktérem v této souvislosti se jeví armáda (potažmo koaliční jednotky či mírová vojska OSN) zasahujících sil, která bývá v konfliktu přítomna. Ačkoliv se toto řešení prrímo nabízí, situace je v praxi mnohem složitější.

Hlavními principy, na kterých si NGOs velmi zakládají, jsou neutralita, nestrannost a nezávislost. Původně vycházející ze základních principů Červeného kř́že, nicméně přijaty byly celým humanitárním sektorem (ICRC). Nejde pouze o etické důvody a princip fungování NGOs samotných, který vyplývá z jejich podstaty, ale jedná se i o bezpečnostní důvody. Pomoc jedné bojující straně na úkor té druhé by automaticky znamenal bezpečnostní riziko pro její zaměstnance. NGOs proto zásadně přistupují neutrálně ke všem bojujícím stranám. Stejně neutrálním zpo̊sobem se snaží zajistit i svou bezpečnost. Udržení neutrality za vyhrocených podmínek násilného konfliktu a masivního ohrožování lidských práv je velmi složité. $V$ rámci bumanitárni operace mư̌̌e neutralita brát natolik quásadni roli, že úspèch néketerých bumanitárnich operaci byl $v$ některých prípadech dán do souvislosti s nedostatkem respektu k, principu neutrality (porušení, etickébo kodexu;

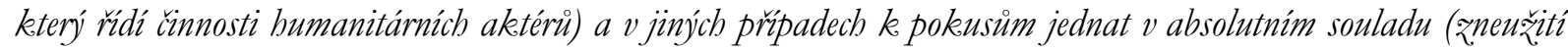
təv. , suverénnich ujednáni" státu v dohodách o bumanitárni pomoci podle vlastnich zájmui) (Ku a Cáceres 2003: 62). Z tohoto důvodu např́iklad spojení s armádou může ve stranách konfliktu automaticky vyvolávat pocit, že NGOs hájí zájmy pouze jedné strany konfliktu, a zvyšovat tak rizika pro NGOs - proto se NGOs obecně spolupráci s armádou spíše vyhýbají. Z výše uvedeného důvodu je velmi důležité vybrat takovou variantu ochrany, aby byla co nejvíce nestranná. Podle Caroliny Holmqvist ze Stockholmského mezinárodního ústavu pro výzkum míru (Stockholm International Peace Research Institute, SIPRI) výběr SVBS na ochranu NGOs „může být citlivou variantou: spíse než jejich spojení s jednou stranou konfliktu, mủže být ochrana skrze [SVBS] považována za účast ,nestranného“ aktéra“" (Holmqvist 2005: 21).

Spolupráce mezi NGOs a armádou je v praxi problematická i z jiných důvodů. NGOs i armáda mají rozdílnou povahu organizace. Armáda je uspořádaná hierarchicky, vojáci pracují v jasných strukturách velení a operačních příkazů, procházejí tvrdým výcvikem, kdežto NGOs jsou více decentralizované a rozhodují se spíše ad hoc podle situace v dané lokalitě (Laipson). NGOs nemají žádnou hierarchickou strukturu a povinnost přijímat rozkazy od osob zvenčí; mají tak mnohem větší svobodu v rozhodování. Armáda někdy nabývá dojmu, že dovede dodat kvalitnější humanitární pomoc než NGOs. Proto se snaží k NGOs př́istupovat direktivním způsobem, což je kontraproduktivní. Př́kladem může být operace v Kosovu, kde se NGOs odmítaly zúčastnit pravidelných porad s armádou, protože měly dojem, že jim budou dávány rozkazy, jak mají pracovat. Komunita NGOs nechtěla být nikým kontrolována a řízena zvenčí. 
Výsledkem této situace bylo, že armádní zdroje nebyly zcela optimálně využity (Abiew 2003: 3031). Misi ve Východním Timoru pro změnu NGOs napadaly z důvodu upřednostňování bezpečnostních témat před humanitárními $\mathrm{v}$ důsledku předchozího plánování celé operace koaličními vojsky (Abiew 2003: 31).

NGOs nerady vidí prímé zapojení armády do distribuce pomoci z důvodu, že humanitární principy a objektivita mohou být zkompromitovány, protože vojenské operace jsou součástí politické agendy. Vojáci nejsou ideálni pro humanitámí práci; nemaji dostatečný výcvik, odborné znalosti a vhodné politické nastaveni pro vybudováni mistnich kapacit a odpovédnosti vǐci mistním obyvatelim; predevšim je ale vojenská činnost inherentně politická a obvykle evokuje př̌slušnost ke stranám - na rozdíl od tradičního bumanitarismu, který je idealizovaný jako morálnè autonomni a politicky nepodminèný č vnucený (Abiew 2003: 30). V Angole tak např́klad rebelové zablokovali operaci NGO z důvodu, že ve stejném uprchlickém táboře spolu s NGO byly př́tomny i jednotky NATO. V jiném př́padě zase samotné NGOs odmítly pomoc od Mise Spojených národů pro pomoc Rwandě (United Nations Assistance Mission for Rwanda, UNAMIR) z obavy, že by se mohly stát nástrojem k prosazování zájmů OSN.

NGOs také nemají zájem sdílet informace s armádou - stejný postoj má i armáda vưči NGOs. NGOs nechtějí armádě poskytovat informace o vládě hostitelské země s tím, že by to mohlo ohrozit jejich misi a př́stup do určitých krizových oblastí. Obávají se také, že armáda usiluje pouze o strategické získání informací. Armáda zase nechce sdílet informace s NGOs kvưli utajení svých operací - např́klad rozmístění jednotek a kapacity (Abiew 2003: 32).

$\mathrm{Na}$ druhé straně NGOs v některých př́ípadech armádu potřebují - např́klad kvůli vytvoření koridorů pro průchod pomoci a distribučních uzlů (Fassin a Pandolfi 2012: 284). Jindy zase spolupráce s armádou nemusí představovat žádné riziko - nejčastěji se jedná o př́pady humanitární krize bez politické dimenze, jako byla mj. operace na Srí Lance v roce 2004 po zásahu vlnou tsunami, kde spolupráce mezi NGOs a armádou USA probíhala zcela bez problémů (např́klad při přepravě) (Laipson). Fred Schreier a Marina Caparini uzavírají využití armády slovy, že „k použití vojenské ochrany na podporu humanitárních operací by mělo dojít pouze v prrípadě, pokud neexistují žádné srovnatelné civilní alternativy“ (Schreier a Caparini 2005: 93).

Z důvodu snahy vyvážit princip neutrality a nestrannosti se některé NGOs rozhodli najmout si lokální „hlídače“ - ozbrojené i neozbrojené - na ochranu svých osob, konvojů, zásob či stanovišt’. Americké NGOs si např́klad běžně najímají lokální ostrahu složenou z místních obyvatel většinou pro ochranu budov a skladů (Perrin 2009: 10). Místní obyvatelé jsou často upřednostňování kvưli znalosti lokálního prostředí, politického zázemí, jazyku a kultury. Navíc se předpokládá, že podporují představu o nestrannosti a neutralitě NGOs, protože nejsou spojeni se státními ozbrojenými silami. Nicméně i lokální zaměstnanci mohou představovat hrozbu. Mohou být např́klad kmenově či etnicky spř́zněni se stranou konfliktu, čímž se NGOs mohou stát terčem útoků. Mají také většinou nedostatek zkušeností a výcviku (Perrin 2009: 10). Někteří členové lokální ochrany začali zaměstnancům NGOs vyhrožovat poté, co byli z NGOs propuštěni (Vaux, Seiple, Nakano a Brabant 2002: 23).

U specifických př́pado̊ se odborníci shodují, že je potřeba vytvořit speciální modely pro ochranu NGOs. Např́klad v Somálsku, které má jedno z největších procent užití ozbrojené ochrany ze strany NGOs, byly vytvořeny jakési „lokální SVBS“ - placené služby byly na základě dohod dodávány lokálními skupinami osob. Napřímo byla najímána ozbrojená ostraha, která pak vystupovala jako zaměstnanci NGOs. V některých částech Somálska jsou ozbrojené stráže a 
doprovod všudypřítomné a jejich využívání je považováno za jediný možný způsob, jak může pokračovat práce NGOs (Stoddard, Harmer a DiDomenico 2009: 12).

Jiným př́padem je Irák; NGOs, které pracují jako př́mí partneři vlády USA, mají předepsáno, že na svou ochranu musejí používat ozbrojené SVBS - bez ohledu na to, zda to tak NGOs chtějí. Podobné př́pady povinné ochrany jsou zaznamenány i v Somalilandu, Jižním Sudánu, Pákistánu, Severním Kavkaze a Keni, kde lokální autority požadují, aby humanitární aktérí využívali ochrany národních armád nebo policie, za což je jim poskytnuta kompenzace (Stoddard, Harmer a DiDomenico 2009: 12).

\section{Zajištění kontroly SVBS}

NGOs a humanitární agentury jsou zodpovědné za užívání svých SVBS. Z tohoto důvodu by si organizace měly vytvořit vlastní předpisy a pokyny, které by měly koordinovat spolupráci se SVBS - zejména s ohledem na dodržování mezinárodního humanitárního práva a lidských práv, na kterých si všechny humanitární organizace velmi zakládají (Perrin 2008). NGOs samy zmiňují užívání SVBS, zatím ale velká část z nich nevytvořila žádný platný jednotný rámec pro tuto spolupráci (Spearin 2007: 13). Např́klad jeden expert na humanitární bezpečnost ve výzkumu Petera W. Singera uvedl, že věděl pouze o jediné NGO, která měla vypracované pokyny pro zaměstnance SVBS; včetně pravidel pro užití zbraní. Tato organizace přesto měla potíže tyto instrukce zavést $\mathrm{v}$ praxi $\mathrm{v}$ důsledku nedostatku odborných znalostí týmu, který působil prímo v místě humanitární operace (Singer 2006). InterAction má zase pro změnu velmi podrobně zpracované instrukce pro partnerství s armádou spolupracující na výcviku, peacekeepingu či pomoci, ale již nemá žádné podrobné instrukce pro SVBS (InterAction 2007).

Aby byla spolupráce skutečně efektivní a nepoškozovala NGOs a SVBS či třetí strany, je potřeba rozvijet osvědčené postupy (best practice) a etické kodexy (code of conduts) - stejně jako v jiných podnikatelských odvětvích. Nicméně je potřeba si uvědomit, že etické kodexy nejsou v praxi nijak vymahatelné a tvoří pouze malou část regulačního rámce ${ }^{18}$. „NGOs jsou roztřrištěnou oblastí korporátního světa s různými mandáty a misemi, které nepodporují sjednocení přístupu či touhu k seberegulaci“" (Spearin 2007: 14).

Jedním z pokusů o regulaci a tvorbu vodítka pro užívání SVBS je Dokument z.Montreux (Montreux Document ${ }^{19}$, iniciovaný právním oddělením švýcarského Ministerstva zahraničí společně s Mezinárodním výborem Červeného kř́že. Dokument byl finalizován v roce 2008; na jeho př́pravách se podílelo 17 státư $^{20}$ a dalších 26 státú $^{21}$ se $\mathrm{k}$ němu do konce října 2012 připojilo, včetně celé Evropské unie (Schweizerische Eidgenossenschaft web). Stal se také oficiálním dokumentem OSN (zároveň byl přijat všemi členy stálé Rady bezpečnosti OSN).

Jeho cílem je prredevším dodržování mezinárodního humanitárního práva a lidských práv ze strany SVBS. Dokument obsahuje rovněž soubor nejlepších postupů a praktik, jak upravovat

\footnotetext{
${ }^{18}$ Regulace SVBS může probíhat na mezinárodní úrovni skrze mezinárodní právo, na národní úrovni skrze právo jednotlivých států, či skrze tzv. seberegulaci - tedy např́iklad formou tvorby etických kodexů či pomocí smluvního ošetření. Více o problematice regulace SVBS viz Bureš Nedědická (2011b)

${ }^{19}$ Celý název dokumentu: Montreux Document on Pertinent International Legal Obligations and Good Practices for States related to Operations of Private Military and Security Companies during Armed Conflict.

${ }^{20}$ Afghánistán, Angola, Austrálie, Čína, Francie, Irák, Jihoafrická republika, Kanada, Německo, Polsko, Rakousko, Sierra Leone, Švédsko, Švýcarsko, Ukrajina, USA a Velká Británie (Schweizerische Eidgenossenschaft).

${ }^{21}$ Albánie, Belgie, Bosna a Hercegovina, Bývalá jugoslávská republika Makedonie, Čile, Dánsko, Ekvádor, Finsko, Gruzie, Island, Itálie, Jordánsko, Katar, Kostarika, Kypr, Lichtenštejnsko, Litva, Mad’arsko, Nizozemí, Norsko, Portugalsko, Řecko, Slovinsko, Španělsko, Uganda, Urugay (Schweizerische Eidgenossenschaft).
} 
chování těchto společností, nicméně je zaměřen především na jejich užívání z pohledu státůa a zabývá se tak odpovědností států za jimi nasmlouvané SVBS. Přesto je v článku 8 v Předmluvě uvedeno, že „zatímco je tento dokument adresován Státům, osvědčené postupy mohou být užitečné i pro jiné entity jako mezinárodní organizace, NGOs a společnosti, které si SVBS najímají, stejně jako pro SVBS samotné“ (Montreaux Document 2008: Preface 8). Dále př́imo zdůrazňuje: „V mnoha př́padech mohou osvědčené postupy pro Smluvní státy ${ }^{22}$ ukazovat osvědčené postupy i pro další klienty SVBS jako mezinárodní organizace, NGOs a firmy“ (Montreaux Document 2008).

$\mathrm{Na}$ Dokument z.Montreux navázala organizace Centrum pro demokratickou kontrolu ozbrojených sil (Centre for the Democratic Control of Armed Forces, DCAF) a ve spolupráci se švýcarskou vládou vytvořila Mezinárodni etický kodex pro soukromé poskytovatele beapečnostnich služeb (International Code of Conduct for Provate Security Service Providers, ICoC) (Centre for the Democratic Control of Armed Forces). Kodex byl vytvořen jako pokyny přímo pro SVBS (na rozdíl od Dokumentu z. Montreux, který byl určený státům). Do 1. řijna 2012 se ke kodexu připojilo 511 společností, včetně těch, které již byly v tomto textu dříve jmenovány. Kodex je založený především na respektování lidských práv. Zahrnuje pravidla pro užití síly, zakazuje mučení, obchodování s lidmi a další formy zneužívání. Dále specifikuje požadavky na společnosti, jejich management a řízení, včetně jejich subdodavatelů. Nicméně jedná se pouze o samoregulační dokument, který opět nemá závaznost, a pro společnosti neplynou žádné právní důsledky z toho, pokud jej nedodrží. Pro NGOs je nicméně dodržování základních pravidel a postupů velmi kritické, protože každý spáchaný incident může je samotné i jejich klienty značně ohrozit (Cockayne 2006: ii). Pro SVBS je reputace velmi důležitá. Z tohoto důvodu je v jejich zájmu etický kodex, stejně jako další normy a národní a mezinárodní zákony, dodržovat, aby se u svých klientů nezdiskreditovali a tím neohrozily budoucí zakázky a zdroj svého př́imu (Avant 2004: 219-221).

Etický kodex nemusí zajišt’ovat, že využívání SVBS v praxi není bezproblémové. NGOs si obecně nedostatečně předávají informace o SVBS jak mezi sebou (Stoddard, Harmer, DiDomenico 2009: 23), tak i mezi vlastními pobočkami. Kontroly SVBS a jejich zaměstnanců jsou ze strany NGOs ojedinělé a často na ad hoc bázi. Některé NGOs tak ve skutečnosti zaměstnávají bývalé vojenské vůdce, kteří se pak sami označí za SVBS. Nesdílejí ani informace o výkonu jednotlivých SVBS, čímž je pro ně složité vědět, jaké služby si vlastně nakupují. Také standardy pro užití zbraně v humanitárních a postkonfliktních podmínkách málokdy odpovídají mezinárodním standardům pro užití ozbrojené síly. Nejhorší obavy nad SVBS panují především u využívání lokálních společností, které jsou jak nedostatečně dozorované, tak poskytují velmi nízkou úroveň služeb (Stoddard, Harmer, DiDomenico 2009: 23). Smlouvy jsou často velmi těžko vymahatelné, protože chybí účinná právní opatření. Humanitární instituce a organizace postrádají centralizované disciplinární a odpovědnostní řízení, které by byly povinny zajistit (Cockayne 2006).

\section{Závěr}

Tento článek se čtenářům pokusil nastínit problematiku využívání SVBS neziskovými organizacemi, a to jak z pohledu vývoje, tak některých motivů, které NGOs nahrávají k tomu, aby na svou ochranu najímaly právě tyto společnosti. Spolupráce a ochrana NGOs je jednou

\footnotetext{
22 Poznámka autorky: Smluvním státem je myšlen stát, který si najme SVBS.
} 
z nových zajímavých oblastí, jak by mohl být využit potenciál SVBS. Ukazuje se, že zaměstnanci NGOs jsou při svém působení v humanitárních operacích - zejména v oblastech, kde probíhá konflikt - vystaveni tak vysoké míře rizika, že je jednoznačně potřeba zavést pro ně ochranná opatření. Přestože jsou stále vedeny diskuze o vhodnosti využívání SVBS jako takových (a to nejen z pohledu NGOs, ale i armády a OSN), SVBS často nejen že mohou představovat vhodnou alternativu pro zajištění bezpečnosti z důvodu svého apolitického postavení, ale v některých př́padech mohou být dokonce jedinou volbou mezi žádnou ochranou a nějakou ochranou. Někdy se tedy NGOs těmto společnostem vyhnout nemohou, ačkoliv jejich využívání apriori nepodporují. NGOs by $\mathrm{v}$ takových př́ípadech z důvodu velmi vysokého bezpečnostního rizika museli svou humanitární operaci zcela zrušit, což by jim znemožnilo poskytovat jakoukoliv pomoc. Není proto překvapením, že NGOs často spoléhají právě na SVBS (Leander 2005: 617).

Velký vliv na užívání SVBS neziskovými organizacemi má samožrejmě i finanční zajištění organizace (které plyne z dotací, př́íspěvků a grantů), tedy zda si takové služby může dovolit. Nedostatek financí může být překážkou především pro malé NGOs, jak např́klad popsala konzultantka z jedné NGO: Moje organizace, malá NGO pracujici na budováni občanské společnosti $v$ Iráku, nebyla vyjimkou [při nutnosti zajištění bezpečnosti od SVBS přikázané USAID]. Príbližñe $40 \%$ našeho šedesátimilionovébo roąpočtu prïpadlo na ocbranu 15 mezinárodnich zamèstnanciu. Naše beapečnostni společnost byla z Jihoafrické republiky (Engler 2010). Nicméně jak již bylo zmíněno dřive, využívání SVBS neziskovými organizacemi není výjimkou, a z toho důvodu lze usuzovat, že finanční prostředky nejsou pro všechny NGOs nedostupné. Zejména velké mezinárodní organizace typu Oxfam, Lékaři bez hranic či Save the Children jsou schopny do bezpečnosti investovat a zajistit si ji skrze SVBS.

Jak v současné době spolupráce mezi NGOs a SVBS v praxi probíhá, tak na jedné straně odhaluje možnosti využití SVBS a některé jejich př́nosy, nicméně na straně druhé straně se ukazují i jejich nedostatky, které mohou být zaviněné samotnými SVBS a jejich nedostatečnými zkušenostmi či kompetencí (zejména u menších místních SVBS), ale také nedostatečně seriózním př́stupem NGOs k jejich využívání (nedostatečnou kontrolu, zajišstování informacî). Pro lepší využívání SVBS ze strany NGOs je proto velmi důležité vytvořit: 1) standardy (základní podmínky a požadavky na SVBS, jejich podobu, strukturu, zkušenosti, management apod.); 2) postupy (instrukce a pokyny pro spolupráci s NGOs, modelové situace); 3) kontrolu (konkrétní dohled nad SVBS v různých situacích, zpětná vazba o jejich provádění úkolů, audit); 4) mechanismus stížností (kdy a jak si stěžovat na určité porušení předpisů SVBS, iniciace nápravného řízenî); 5) možnost postihnout SVBS (možnost trestu při porušení pravidel, spáchání trestného činu, neprovedení nápravného opatření - toto je z velké části úkolem právního rámce a zajištění jeho vymahatelnosti, což NGOs bohužel nemohou z velké části ovlivnit).

Z článku jednoznačně vyplývá, že využití SVBS se v současnosti jeví jako jedna z přijatelných alternativ pro zajištění ochrany NGOs, a to především k povaze NGOs samotných, které si chtějí uchovat svou nezávislost a neutralitu. Z výše uvedeného zatím také můžeme předpokládat, že současné využívání SVBS v humanitárním sektoru bude i nadále pokračovat, nicméně tím hlavním, čím by se zainteresovaní aktéŕi měli zabývat, je zlepšování procesů a postupů pro využívání SVBS, pokud mají NGOs skutečně pomoci a nepřispívat naopak k dalším bezpečnostním hrozbám. 


\section{Literatura}

Abiew, F. K., „NGO (2003): Military Relations in Peace Operations, in: Carey, H. F. - Richmond, O. P. (eds.): Mitigating Conflict: The Role of NGOs, London, Frank Cass Publishers.

Alger, Ch. F. (2005): Expanding Involvement of NGOs in Emerging Global Governance, in: Richmond, O. P. - Carey, H. F. (eds.): Subcontracting Peace: The Challanges of the NGO Peacebuilding, Farnham, Surrey, Ashgate.

Anders, H. (2007): The UN Process on Small Arms: All Is Not Lost, Arms Control Association, http://www.armscontrol.org/act/2007_03/Anders (cit. 18. 11. 2012).

Atassi, B. (2012): Caught between arms and politics, Al Jazeera. http://www.aljazeera.com/focus/2010/08/20108199227928620.html (cit. 17. 11. 2012).

Avant, D. D (2004): The Market for Force: The Consequences of Privatizing Security, Cambridge, Cambridge University Press.

Avant, D. D. (2007): NGOs, Corporations and Security Transformation in Africa, International Relations, roč. 21, č. 2, s. 143-161.

BBC News: Q\&A: Who are Somalia's al-Shabab?, http://www.bbc.co.uk/news/world-africa-15336689 (cit. 20. 11. 2012).

Beuns, S. P. (2007): Warriors for the Working Day: Private Military Firms in Conflict, Journal of Global Change and Governance roč. 1, č. 1, s. 1-23.

Boemcken, M. (2007): Liaisons Dangereuses: The Cooperation between Private Security Sompanies and Humanitarian Aid Agencies, in: (Järger, T. - Kümmel, B. (eds.): Private Military and Security Companies: Chances, Problems, Pitfalls and Prospects, Wiesbaden: VS Verlag für Sozialwissenschaften.

Brayton, S. (2002): Outsourcing War: Mercenaries and the Privatisation of Peacekeeping, Journal of International Studies, roč. 55, č. 2, s. 303-329.

Bryans, M. - Jones, B. D. - Stein, J. G. (1999): Mean Times: Humanitarian Action in Complex Political Emergencies - Stark Choices, Cruel Dilemmas: Report of the NGOs in Complex Emergencies Project, Toronto, Program on Conflict Management and Negotation, Center for International Studies, University of Toronto.

Buchanan, C. - Muggah, R. (2005): No Relief: Surveying the Effects of Gun Violence on Humanitarian and Development Personnel, Center for Humanitarian Development, http://www.seesac.org/sasp2/english/publications/1/Impact/5_SALW_Impact.pdf (cit. 8. 11. 2012).

Bureš, O. - Nedědická, V. (2011a), Historie využívání soukromých vojenských sil, Vojenské rozhledy roč. 52, č. 3, s. 76-93.

Bureš, O. - Nedědická, V. (2011b). Soukromé vojenské společnosti: Staronoví aktéři mezinárodního politického systému, Plzeň: Aleš Čeněk

Buzatu, A-M. - Buckland, B.S. (2012): Private Military \& Securrity Companies: Future Challanges in Security Governance, DCAF Horizon 2015 Working Paper no. 3., Geneva, The Geneva Centre for the Democratic Control of Armed Forces.

Byman, D. (2011): Uncertain Parameters: NGOs and the Military, Survival, roč. 43, č. 2, s. 97-114.

CARE International, History, http://www.care-international.org/History/ (cit. 5. 11. 2012).

Centre for the Democratic Control of Armed Forces. DCAF, International Code of Conduct for Provate Security Service Providers, http://www.dcaf.ch/Project/International-Code-of-Conduct-for-PrivateSecurity-Service-Providers (cit. 22. 11. 2012). 
Cockayne, J. (2006): Commercial Security in Humanitarian and Post-Conflict Settings: An Exploratory Study, New York: International Peace Academy, http://www.ipinst.org/media/pdf/publications/commercial_security_final.pdf (cit. 22. 11. 2012).

Coll, S. (2012): Looking for Mullah Omar, The New Yorker, http://www.newyorker.com/reporting/2012/01/23/120123fa_fact_coll (cit. 17. 11. 2012).

Deschamps, S. (2005): Towards the use of the Private Military Companies in the United Nations Peacekeeping Operations, Peace Operations Training Institute.

Dupuy, P.-M. - Vierucci, L. (2008): NGOs in International Law: Efficiency in Flexibility?, Northampton, Edward Elgar Publishing, Inc.

Ebo, A. (2008): Private actors and the Governance of Security in West Africa, in: Andrew, A. - Baker, D. P. - Caparini, M. (eds.): Private Military and Security Companies, policies and civil-military relations, New York, Routledge.

Egeland, J. - Harmer, A. - Stoddard, A. (2011): To Stay and Deliver: Good practice for humanitarians in complex security envionments, United Nations, http://www.dgvn.de/fileadmin/user_upload/menschl_entw/FKP/Stay_and_Deliver_Feb_17_1_.p df (cit. 4. 11. 2012).

Engler, Y. (2010), NGO Ties to Private Security Companies, Dissident Voice, http://dissidentvoice.org/2010/08/ngo-ties-to-private-security-companies/(cit. 19. 11. 2012).

European Convention on the Recognition of the Legal Personality of International Non-Governmental Organisations, Article 1, Strasbourg, 24.IV.1986.

Fassin, D. - Pandolfi, M. (2012): Contemporary States of Emergency: The Politics of Military and Humanitarian Intervensions, Brooklyn, Zone Books.

G4S, NGOs, http://www.g4s.co.ke/en-KE/What\%20we\%20do/Sectors/Government/NGOs/ (cit. 19. 11. 2012).

Geneva Centre for the Democratic Control of Armed Forces (2004): Private Military Firms, Geneva, DCAF.

Ghebali, V.-Y. (2008): The United Nations and the Dilemma of Outsourcing Peacekeeping Operation, in: Bryden, A. - Caparini, M. (eds.): Private Actors and Security Governance, Geneva, Geneva Centre for the Democratic Control of Armed Forces.

Holmqvist, C. (2005): Private Security Companies: The Case for Regulation, Policy Paper No. 9. Stockholm: Stockholm International Peace Research Institute.

ICRC, The Fundamental Principles of the Red Cross: commentary, http://www.icrc.org/eng/resources/documents/misc/fundamental-principles-commentary010179.htm (cit. 20. 11. 2012).

InterAction (2007): InterAction US Civilian-Military Guidelines, http://www.interaction.org/document/interaction-us-civilian-military-guidelines-july-2007 (cit. 18. 11. 2012).

InterAction (2007): InterAction US Civilian-Military Guidelines, http://www.interaction.org/document/interaction-us-civilian-military-guidelines-july-2007 (cit. 18. 11. 2012).

International Committee of the Red Cross (2004): The ICR to Expand Contratcs with Private Military and Security Companies, http://www.icrc.org/eng/resources/documents/misc/63he58.htm (cit. 13. 11. 2012).

International Committee of the Red Cross, History, http://www.icrc.org/eng/who-weare/history/index.jsp (cit. 5. 11. 2012). 
Isenberg, D. (2009), Outsourcing Peacekeeping, CATO Institute, http://www.cato.org/publications/commentary/outsourcing-peacekeeping (cit. 4. 11. 2012).

Jelinek, E. (2009): NGO Relations with the Government and Communities in Afghanistan, Humanitarian Exchange Magazine, č. 42, http://www.odihpn.org/humanitarian-exchange-magazine/issue-42/ngorelations-with-the-government-and-communities-in-afghanistan (cit. 19. 11. 2012).

Jurriaans, K-J. (2012): U.N. Increasingly Reliant on Private Security Contractors, Inter Press Service, http://www.ipsnews.net/2012/07/u-n-increasingly-reliant-on-private-security-contractors/ (cit. 2. 11. 2012).

Keen, D. J. (2008): Complex Emergencies, Cambridge, Polity Press.

Ku, Ch. - Cáceres, J. (2003): Neutrality and the ICRC Contributions to Contemporary Humanitarian Operations, in: Carey, H. F. - Richmond, O. P. (eds.): Mitigating Conflict: The Role of NGOs, London, Frank Cass Publishers.

Laipson, E. B.: Can the USG and NGOs Do More?: Information-Sharing in Conflict Zones, Central Intelligence Agency, https://www.cia.gov/library/center-for-the-study-of-intelligence/csipublications/csi-studies/studies/vol49no4/USG_NGOs_5.htm (cit. 20.11. 2012).

Lawry, Lynn (2009, ed.): Guide to Nongovernmental Organizations for the Military: A primer for the military about private, voluntary, and nongovernmental organizations operating in humanitarian emergencies globally, The Center for Disaster and Humanitarian Assistance Medicine (CDHAM), Uniformed Services University of Health Sciences (USUHS), International Health Division, Office of the Assistant Secretary of Defense (Health Affairs), U.S. Department of Defense,

http://www.dmrti.army.mil/documents/NGO_Guide_for_the_Military\%20sflb\%20ashx.pdf (cit. 4. 11. 2012).

Leander, A. (2005): The Market for Force and Public Security: The Destabilizing Consequences of Private Military Companies, Journal of Peace Research, roč. 42, č. 5, s. 605-622. DOI: $10.1177 / 0022343305056237$

Lewis, D. J. (2007): Management of Non-Governmental Development Organisations, New York, Routlege, 2007.

Lilly, D. (2000): The Privatization of Security and Peacebuilding: A Framework for Action, London, International Alert.

Mandel, R. (2001): The Privatization of Security, Armed Forces and Society, roč. 28, č. 1, s. 129-151.

Margesson, R. - Dagne, T. - Hanrahan, CH. E. (2012, eds.): Horn of Africa Region: The Humanitarian Crisis and International Response, Congressional Research Service: Report for Congress, http://www.fas.org/sgp/crs/row/R42046.pdf_(cit. 17. 11. 2012).

Mathews, J. T. (1997): Power Shift, The Foreign Affairs, roč. 76, č. 1, s. 50-66.

McGrann, J. - Johnstone, M. (2006): The Power Shift and the NGO Credibility Crisis, The International Journal of Not-for-Profit Law, roč. 8, č. 2, s. 65-77.

Mears, E. S. (2009): Private Military and Security Companies and Humanitarian Action, Security Management Initiative.

Montreux Document on Pertinent International Legal Obligations and Good Practices for States related to Operations of Private Military and Security Companies during Armed Conflict. 17 September 2008. Preface 8, http://www.icrc.org/eng/assets/files/other/icrc_002_0996.pdf (cit. 19. 11. 2012).

Ostensen, A. G. (2009): Outsourcing Peace? The United Nations's Use of Private Security and Military Companies, Saarbrücken, VDM Verlag Dr. Müller.

Ostensen, A. G. (2012): UN Use of Private Military and Security Companies: Practices and Policies, Geneva, The Geneva Centre for the Democratic Control of Armed Forces, Paper 3. 
Perito, R. M. (2007, ed.): Guide for Participants in Peace, Stability, and Relief Operations, Washington D.C., United States Insitute of Peace Press.

Perrin, B. (2008): Humanitarian Assistance and the Provate Security Debate: An International Humanitarian Law Perspective, On the Edges of Conflict, Ottawa, Canadian Red Cross, http://www.croixrouge.ca/cmslib/general/oteoc_ben_perrin.pdf (cit. 22. 11. 2012).

Perrin, B. (2009): Humanitarian Organizations \& The Private Security Debate: Implications for International Humanitarian Law, http://www.isisc.org/portal/images/stories/PDF/Paper\%20Perrin.pdf (cit. 15. 11. 2012)

Rewards for Justice, Wanted Information leading to the location of Mullah Omar Up to $\$ 10$ Million Reward, http://www.rewardsforjustice.net/english/index.cfm?page=MullahOmar (cit. 17. 11. 2012). Schreier, F. - Caparini, M. (2005): Privatising Security: Law, Practice and Governance of Private Military and Security Companies, Geneva Centre for the Democratic Control of Armed Forces, Occasional Paper No. 6., Geneva, DCAF.

Schwartz, M. (2011): Department of Defense Contractors in Iraq and Afghanistan: Background and Analysis, Washington D.C., Congressional Research Service.

Schweizerische Eidgenossenschaft, Participating States of the Montreux Document, http://www.eda.admin.ch/eda/en/home/topics/intla/humlaw/pse/parsta.html (cit. 21. 11. 2012).

Singer, P. W. (2003): Peacekeepers Inc., Brookings Institution. Policy Review, http://www.brookings.edu/articles/2003/06usmilitary_singer.aspx (cit. 4. 12. 2012).

Singer, P. W. (2005): Outsourcing War, Foreign Affairs, roč. 84, č. 2, s. 119-120.

Singer, P. W. (2006): Humanitarian principles, private military agents: some implications of the privatised military industry for the humanitarian community, in: Wheeler, V. - Harmer, A. (eds.): Resetting the Rules of Engagement: Trends and Issues in Military-Humanitarian Relations, London, HPG Report 22.

Singer, P. W. (2007): Corporate Warriors: The Rise of the Privatised Military Industry, Ithaca and London, Coronell University Press.

Spearin, Ch. (2000): A Private Security Panacea? A Response to Mean Times on Securing the Humanitarian Space, Second Annual Graduate Student Seminar, Canadian Centre for Foreign Policy Development, http://www.sandline.com/hotlinks/Chris_Spearin-en.html (cit. 19. 11. 2012).

Spearin, Ch. (2007): Humanitarian Non-Governmental Organizations and International Private Security Companies: The "Humanitarian" Challenges of Moulding a Marketplace, Geneva: Geneva Centre for Democratic Control of Armed Forces,

Stoddard, A. - Harmer, A. - DiDomenico, V.(2009): Private security contracting in humanitarian operations, HPG Polici Brief 33, http://www.odi.org.uk/sites/odi.org.uk/files/odiassets/publications-opinion-files/3735.pdf (cit. 4. 11. 2012).

Stoddard, A. - Harmer, A. - Haver, K. (2011): Aid Worker Security Report 2011, Humanitarian Outcomes, http://www.humanitarianoutcomes.org/resources/AidWorkerSecurityReport20112.pdf (cit. 4. 11. 2012).

Stohl, R. - Hogendoorn, E. (2012): Stopping the Destructive Spread of Small Arms How Small Arms and Light Weapons Proliferation Undermines Security and Development, Center for American Progress, http://www.muntr.org/v4/wp-content/uploads/2012/02/Center.pdf (cit. 13. 11. 2012).

The Fund for Peace, The Failed States Index, http://www.fundforpeace.org/global/?q=fsi, http://www.relooney.info/SI_Expeditionary/Post-Conflict-Economic-Development_73.pdf_cit. 19. 11. 2012). 
The Independent (2008): ArmorGroup sold to G4S after sharp fall in profits, http://www.independent.co.uk/news/business/news/armorgroup-sold-to-g4s-after-sharp-fall-inprofits-799044.html (cit. 7. 11. 2012).

The Intenrational Committee of the Red Cross, Code of Conduct, http://www.ifrc.org/en/publicationsand-reports/code-of-conduct/(cit. 7. 11. 2012).

The International Code of Conduct for Private Security Service Providers Signatory Companies, http://www.icoc-psp.org/uploads/Signatory_Companies_-_October_2012_-

_Composite_List_SHORT_VERSION.pdf (cit. 22. 11. 2012).

The UN Refugee Agency, 1.3 The Security Triangle (Acceptance, Protection, Deterrence), http://www.mofa.go.jp/mofaj/gaiko/oda/shimin/oda_ngo/shien/kiki_ws05/pdfs/kiki_ws05_0502 .pdf (cit. 10. 11. 2012).

The World Bank, Defining Civil Society, http://web.worldbank.org/WBSITE/EXTERNAL/TOPICS/CSO/0, contentMDK:20101499 me nuPK:244752 pagePK:220503 piPK:220476 theSitePK:228717,00.html (cit. 3. 11. 2012).

United Nations (2009): Draft International Convention on the Regulation, Oversight and Monitoring Of Private Military and Security Companies, http://mgimo.ru/files/121626/draft.pdf (cit. 2. 11. 2012).

United Nations Office for Disarmament Affairs, Small Arms, http://www.un.org/disarmament/convarms/SALW/ (cit. 18. 11. 2012).

United States Government Accountability Office (2006): Darfur Crisis: Progress in Aid and Peace Monitoring Threatened by Ongoing Violence and Operational Challanges, GAO-7-09, http://www.gao.gov/assets/260/253141.html (cit. 18. 11. 2012).

Vaux, T. - Seiple, Ch. - Nakano, G. - Brabant, K. (2002): Humanitarian Action and Private Security Companies: Opening the Debate, London, International Alert.

Vedder, A. (2007): NGO Involvement in International Governance and Policy: Sources of Legitimacy, Netherlands, Mrtinus Nijhoff Publishers and VSP.

Wallacher, H., - Harang, A. (2011): Small, But Lethal - Small Arms Ammunition and the Arms Trade Treaty, PRIO, http://controlarms.org/wordpress/wp-content/uploads/2011/03/Small-but-LethalSmall-Arms-Ammunition-and-the-Arms-Trade-Treaty.PRIO.pdf (cit. 18. 11. 2012).

Wodarg, W. (2008): Private military and security firms and the erosion of the satet monopoly on the use of force, Report: Council of Europe, Political Affairs Committee, http://assembly.coe.int/Documents/WorkingDocs/Doc08/EDOC11787 (cit. 18. 11. 2012).

\section{Private Military and Security Companies and the Potential for their Use by Non-Governmental Organisations}

\section{SUMMARY}

The paper deals with private military and security companies (PMSCs) and the provision of their services to non-governmental organisations (NGOs). Each is a new interesting actor in international relations coming from a completely different background - one is from the private sector, and the other from the non-profit sector. Today, both are simultaneously entering the area of international security, which, in the past, was traditionally mainly the domain of state actors. 
The paper begins with a definition of NGOs and then focuses on the dilemma regarding the definition of PMSCs, giving examples of definitions widely accepted either by academics or institutions. It also provides a brief overview of the security environment from 1990 to date and how PMSCs and NGOs have developed since then. 1990 is an important milestone as, since the end of the Cold War, PMSCs begun to flourish around the world due to massive changes in the security area caused by the disarmament of states, the transfer of security capacities to the private sector, and blurred lines of conflicts. Meanwhile, political changes have enabled NGOs to expand their scope of activities and enter new territories which pose new risks to these organisations and their employees.

There is also an analysis of the main motivations behind the decisions of NGOs to use the services of PMSCs, giving several examples of when their services were used in practice. One of the biggest such motivations is the need for security for NGO employees. NGOs often tend to operate in extremely unstable environments in countries affected by war, humanitarian crises, and natural disasters, and in post-conflict areas with minimal institutional arrangements and infrastructure. Easy access to arms worldwide increases the security threats which the NGOs' employees are exposed to. NGOs also handle large quantities of goods such as food, water, medical supplies, and electronic devices etc. In unstable territories the value of such goods is immense, which then increases the risks to NGO employees still further. As some examples in the paper show, there are countries which rely heavily on their citizens catering for their own safety by carrying weapons as a means of deterrence in the face of any threat, and this context applies to NGOs as well..

In their work, NGOs apply three main principles: independence, neutrality and impartiality. Adherence to these principles limits to a great extent their efforts to ensure their own safety. NGOs do not want to be involved in any kind of co-operation with national armies or armed groups. Any co-operation with a party in the conflict or a (para)military force which could secure the safety of NGO employees is ruled out by definition; on the other hand, if support is provided by a third party in the conflict, it is still not perceived as totally impartial, primarily by the locals. The paper gives some examples of why co-operation between military forces, national or otherwise, and NGOs does not work in practice.

In the light of these findings PMSCs seem to be the best option for the protection of NGOs. It is an independent player vis-à-vis the parties in the conflict, it can be deployed very quickly if needed, and it can be equally quickly withdrawn if necessary. In addition, it can provide targeted services within the predetermined scope specified by an NGO, ranging from risk analysis and assessment, to the training of employees and the provision of personal armed security. NGOs can select from a wide range of companies including large international corporations as well as small local firms. If the customer - an NGO - becomes dissatisfied with the level of services, he can relatively easily terminate the contract, which, in the case of protection provided by regular armed forces, cannot be done so easily.

The paper attempts to explain the basis of co-operation between these two parties during their mission and quotes some examples of services provided by PMSCs to NGOs. This co-operation is compared with that between the United Nations (UN) and PMSCs. The UN also relies on more "defensive" companies such as the former ArmorGroup (acquired by G4S); the services acquired are also similar to those acquired by NGOs. The results of different studies show that NGOs mostly require unarmed protection of facilities and accommodation. In addition to this, all services are 
mainly provided by local PMSCs. These companies are often established by a handful of individuals who are citizens of the affected area and can provide a good knowledge of local conditions, social boundaries and relations, as well as help clients to overcome cultural and language barriers.

Last but not least, the paper considers the key prerequisites for successful co-operation between these two parties. The main obstacle to successful and mutually beneficial co-operation is the lack of control over PMSCs. NGOs frequently lack guidelines for cooperating with PMSCs; however, some of them have guidelines for co-operation with the military. Best practice and codes of conduct should be developed further with the aim of improving co-operation. It is also paramount to develop and apply a common legal framework with legally binding rules. 